\title{
Dáfnis e Cloé, de Longo de Lesbos - Livro segundo: tradução e comentário
}

\author{
Luiz Carlos André Mangia Silva \\ Universidade Estadual de Maringá (UEM) \\ lcamsilva@uem.br
}

\begin{abstract}
RESUMO: Apresentamos aqui a tradução para a língua portuguesa da segunda parte do romance de Longo de Lesbos, intitulado Dáfnis e Cloé, datado de meados do século II d.C. Também conhecida como As Pastorais, a obra não dispõe ainda de tradução integral em português feita diretamente da língua grega. Assim, nossa tradução pretende sanar esta carência e permitir ao leitor um contato mais seguro com o texto original. Nesta segunda parte do romance, podemos ver diferentes ações, entre as quais Dáfnis e Cloé ajudando nos trabalhos ligados à colheita da uva; o incidente com os jovens estrangeiros, que acabam por mover guerra contra os protagonistas; a intervenção guerreira do deus Pã, irritado com a ousadia dos estrangeiros; e finalmente, a celebração dos personagens com banquete e apresentações artísticas.
\end{abstract}

Palavras-chave: Romance grego; tradução; literatura pastoril .

\section{The Greek novel Daphnis and Chloe: a Portuguese translation of the second part with commentary}

\begin{abstract}
This is a Portuguese translation of the second part of Daphnis and Chloe, Longus' novel, dated from the middle of the 2nd century AD. Also known as Pastoral novel, the work does not have a full translation directly from the Greek language to Portuguese yet. Thus, our translation intends to supply this lack and offer to the reader a closer contact with the original text. In this second part of the novel, we can see different actions, including Daphnis and Chloe's help with the work related to the grape harvesting; the incident with young foreigners, who end up waging war against the protagonists; the warlike intervention of the god Pan, angry at the boldness of the foreigners; and finally, the characters' celebration with feasts and artistic presentations.
\end{abstract}

Keywords: Greek novel; translation; pastoral literature. 


\section{Apresentação}

As ações do segundo livro de Dáfnis e Cloé - romance pastoril atribuído a Longo de Lesbos (cerca de II d.C.) - transcorrem todas elas durante a estação do outono. Por ser a época da vindima, o texto abre com todos os personagens envolvidos nas tarefas exigidas pela colheita da uva. Dáfnis e Cloé participam de bom grado destes trabalhos, embora anseiem pelo dia em que poderão voltar, apenas na companhia um do outro, aos cuidados com os rebanhos, fugindo assim do tumulto que envolve tais atividades. Quero destacar, dessa segunda parte do romance (que possui quatro), três cenas em particular, pela sua beleza e importância na narrativa.

A primeira delas é a descrição, feita pelo velho Filetas - amiúde identificado com o poeta Filetas de Cós, celebrado por Teócrito como um dos inventores do gênero bucólico, em III a.C. (LONGO, 1997, p. 66, n. 70; MACHADO, 1996, p. 79, n. 2) -, da criança que ele encontra a colher frutos em seu pomar. Surpreendida, ela lhe foge e se esconde sob as roseiras e as papoulas, de onde lhe atira as bagas de mirtos que tem à mão. Embora devesse ficar irritado com isso, Filetas sente-se enfeitiçado pela criança e nada faz contra ela: apenas lhe pede um beijo e promete-lhe entregar os frutos que ela quiser. Ela ri da proposta e informa que beijar não combina com a velhice de Filetas pois, se ele ficar apaixonado, não será capaz de perseguir seu objeto de desejo. A criança ainda afirma ser mais velha do que o Tempo e o universo, embora não pareça; e que todas as manhãs, depois de reunir Dáfnis e Cloé, vem se banhar nas fontes do pomar de Filetas e se deslumbrar com plantas e flores - eis o motivo por que há ali tamanha abundância, tamanha harmonia: tudo é regado pela água de seus banhos. Depois de dizer essas coisas com uma voz mais bela do que a de um velho cisne, ela trepa nos pés de mirto e de galho em galho atinge o topo. É quando Filetas vê asas em seu dorso e um pequeno arco - e ele então conclui ser Amor, o deus Eros, esta pequena criança, que em seguida desaparece. Notemos que essa genealogia parece fundir o deus primordial de Hesíodo, nascido do Caos (na Teogonia), com atributos claramente helenísticos, de criança travessa e alada armada de flechas. Filetas procura Dáfnis e Cloé para declarar-lhes o que viu e ouviu - que o deus Eros ora se ocupa deles. Esta é a primeira vez que os jovens pastores ouvem o nome da divindade.

Outro ponto alto das ações nesta segunda parte do romance ocorre quando, raptada, Cloé está em posse dos cidadãos de Metimne que investiram como inimigos contra os mitilenos. Pã, por solicitação das Ninfas protetoras da garota, intervém em seu favor, instaurando o pânico entre os raptores, qualidade bem propriamente sua, quando irritado. A cena, como destacam os comentadores (por exemplo, Sanches e Güemes em LONGO, 1997, p. 81, n. 105), 
remete a dois Hinos Homéricos: A Dioniso (VII) e A Apolo (III). Quando Cloé e outros cativos estão sendo levados com seus rebanhos para Metimne, diferentes prodígios passam a acontecer, em terra e em mar. Nos barcos ancorados longe da orla, a tripulação recobra o vigor em uma festa triunfal; de repente, a terra toda parece arder em chamas e o som de navios inimigos se aproximando é claro a todos. Parece já haver feridos e mortos, sem que inimigo algum possa ser visto. Toda a noite transcorre assim. Pela manhã, novos portentos: os bodes de Dáfnis aparecem com os chifres adornados de hera e as ovelhas de Cloé uivam como lobos, enquanto ela própria ostenta, maravilhosamente, uma coroa de ramos de pinheiro, planta consagrada a Pã. Se os raptores tentam fugir, as âncoras permanecem presas no fundo, os remos se partem e golfinhos, com golpes, causam danos no madeirame dos navios. E finalmente um som qual o de uma trombeta é ouvido do alto de um promontório. É quando o comandante dos metimnianos, subitamente lançado em sono, tem uma visão onírica, em que Pã lhe ordena restituir Cloé e seus rebanhos a Mitilene. Só assim seu retorno a Metimne será possível. Prudentemente ele cumpre a ordem e Cloé, uma vez desembarcada, é rodeada por suas ovelhas como por um coro de dançarinas e um som doce de flauta a conduz de volta à casa.

Outra cena memorável, já quase fechando o livro, é a dos familiares de Dáfnis e Cloé celebrando as Ninfas e Pã, pela proteção recebida, na alegre companhia de Filetas e seu filho Títiro. Reunidos próximos da estátua de Pã, nos campos, os convivas ouvem Lamon narrar o mito da origem da flauta, o qual ele ouvira de um pastor siciliano: Pã enamorou-se de uma jovem pastora, chamada Siringe (Flauta), cujo canto mavioso era como o da flauta. Por se recusar a se entregar a ele, perseguida, ela foge enquanto pode, até que cai em um pântano, onde some; Pã, triste pelo ocorrido, colhe do lugar caniços de diferentes tamanhos e faz com eles um instrumento, para recordá-la. Assim surge a flauta, também conhecida como flauta de Pã. Depois dessa narrativa que explica a origem mítica do instrumento, é Filetas quem exibe seus dons de flautista. Dono de uma flauta que em tudo se assemelha à descrita na narrativa de Lamon, ele toca de tal modo que parece haver várias flautas sendo tocadas ao mesmo tempo; depois, diminuindo a intensidade, ele entoa uma doce melodia para, a seguir, demonstrar o flauteado próprio para tanger cada tipo de rebanho, de bois e cabras e ovelhas. Depois dele, é Drias quem dança para os convivas, ao som de uma melodia dionisíaca, uma coreografia de vindima: ele então representa cada uma das ações ligadas à produção do vinho, começando pela colheita, depois o transporte dos cestos, a seguir a pisa de uvas nos lagares, o enchimento dos tonéis e o ato de beber o vinho. Segundo o narrador, tudo é representado com tamanha clareza que todos julgam ver as ações acontecendo. Finalmente Dáfnis e Cloé também se exibem artisticamente: experimentando a flauta de Filetas, ele encarna 
Pã em busca da pastora Siringe; Cloé, a imitá-la, desdenha do seu pretendente e foge e se esconde na floresta, como se sumisse em um pântano. Dáfnis, a procurála, flauteia com doçura tão comovente que Filetas lhe presenteia com a flauta, o que marca, para Dáfnis, uma das etapas de sua introdução na idade adulta.

Destaco ainda, quanto a essa última cena, que a presença dessas variadas expressões artísticas dentro da obra reforçam um traço comum ao romance antigo - o de dialogar com outras artes. Lembro ao leitor que a motivação, segundo o narrador, para compor a história de Dáfnis e Cloé foi a contemplação de uma pintura encantadora sobre o tema (descrita no Livro Primeiro, em seu Proêmio), vista por ele quando visitava Lesbos.

Não disponho ainda de uma edição recente para o texto grego, de modo que consultei o texto fixado por Rudolf Hercher (1858), disponível na plataforma Perseus Digital Library. Depois de enfrentar todas as dificuldades do texto grego, para dirimir dúvidas li a tradução indireta de Duda Machado (1996), distante, todavia, do original; a espanhola de Sanches e Güemes (LONGO, 1997), bem próxima do original e rica em notas; e a inglesa de Turner (LONGUS, 1968). Essas últimas, sobretudo, forneceram-me não poucas vezes o subsídio necessário para a correta interpretação das frases gregas. Além dessas obras devo mencionar a consulta sistemática ao Dicionário Grego-Português de Malhadas-Dezotti-Neves (2006-2010) e ao Dicionário Grego-Inglês de Lidell-Scott-Jones (1940), hospedado no Perseus.

\section{Texto grego}

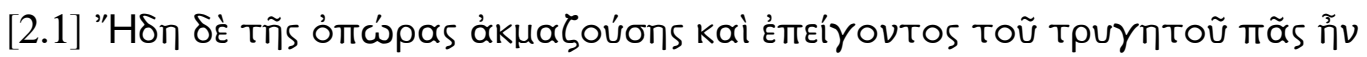

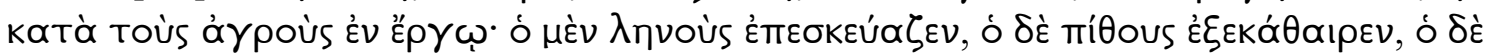

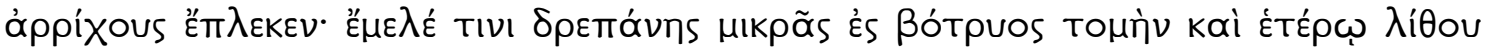

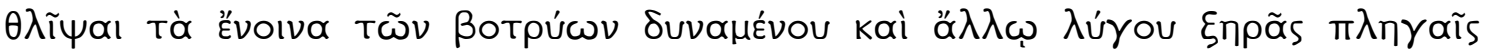

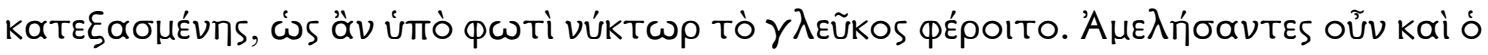

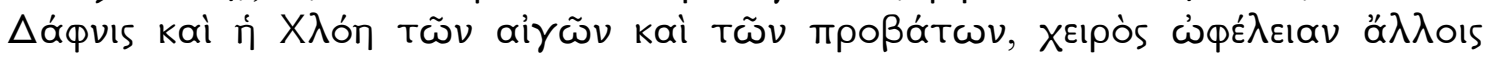

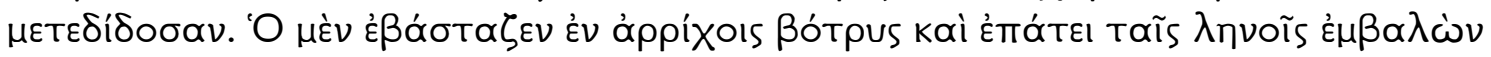

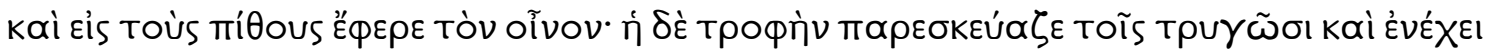

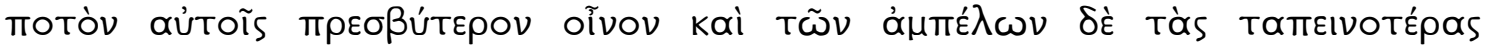

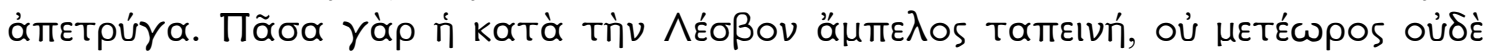

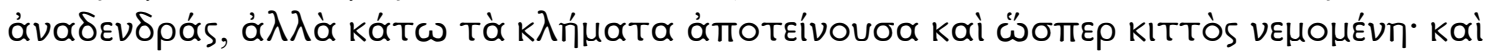

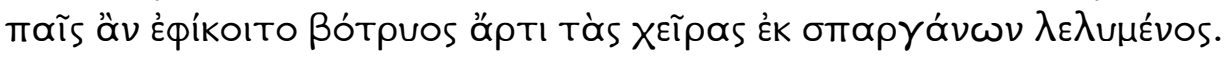

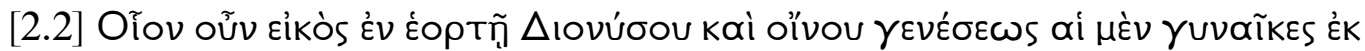

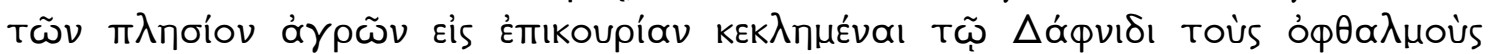

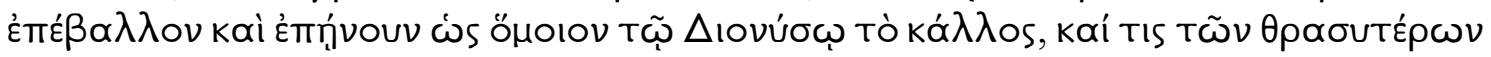

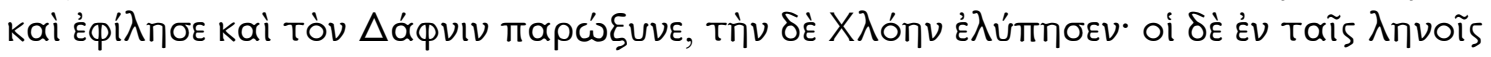

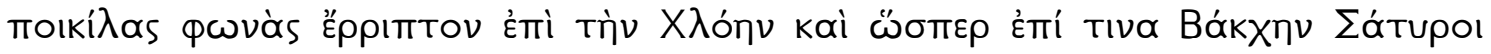

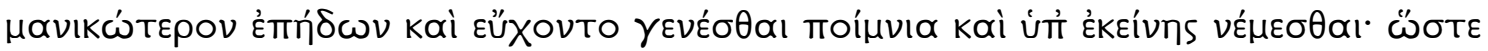

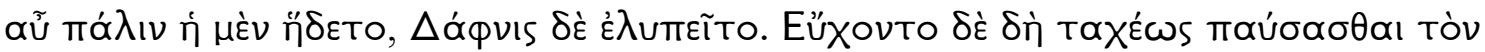




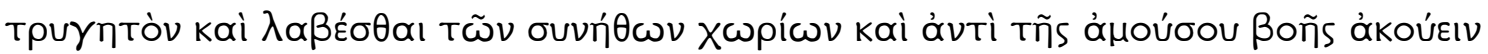

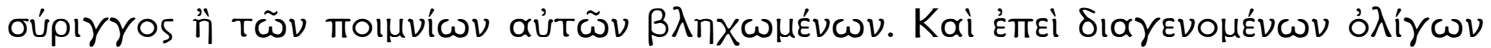

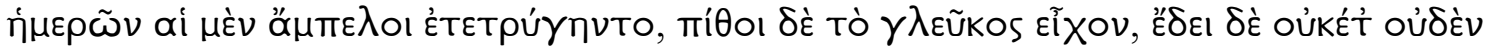

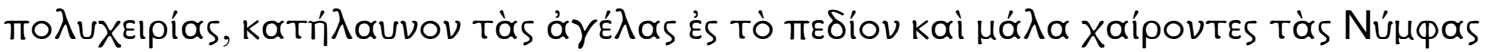

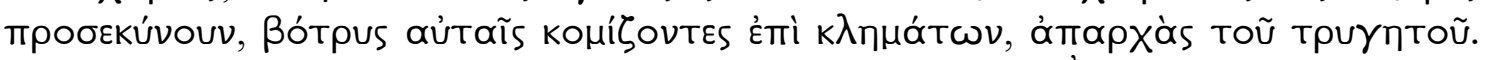

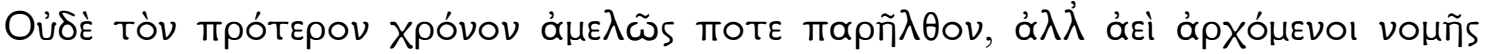

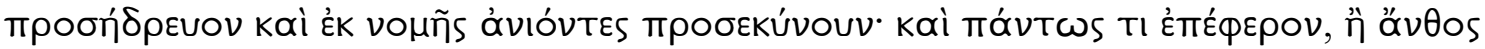

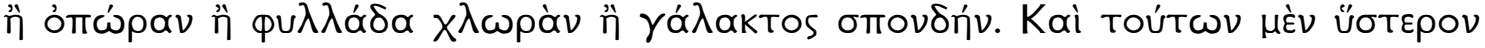

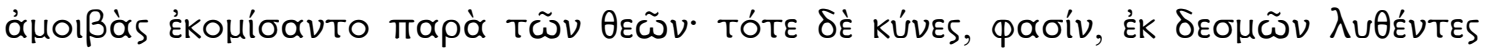

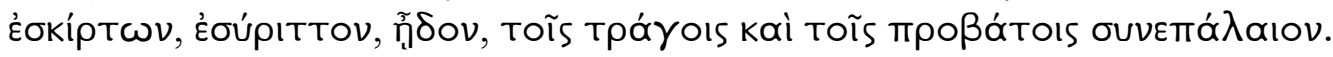

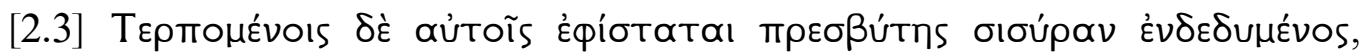

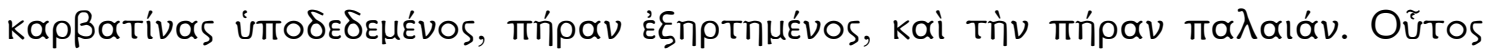

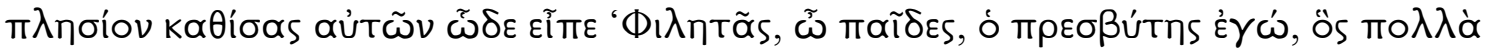

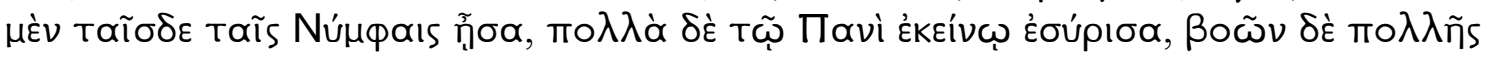

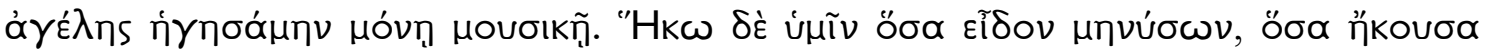

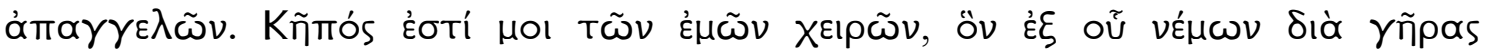

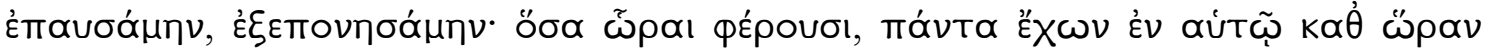

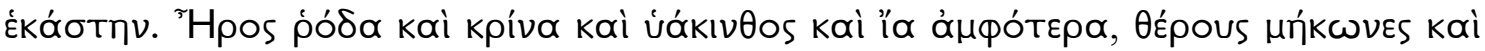

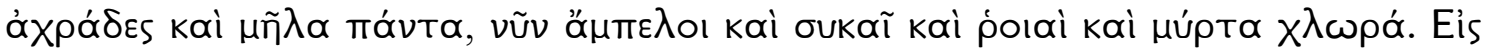

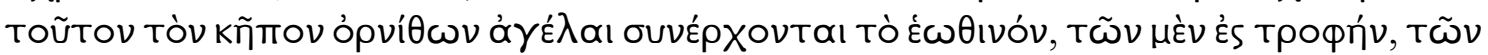

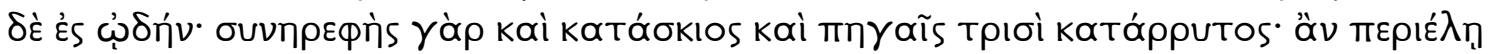

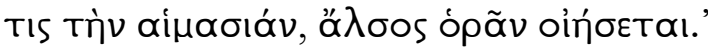

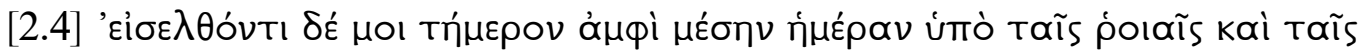

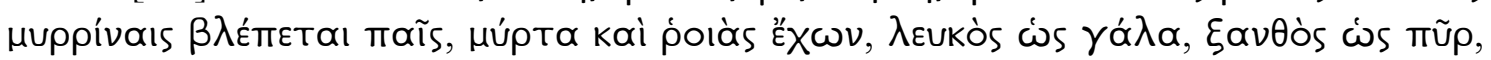

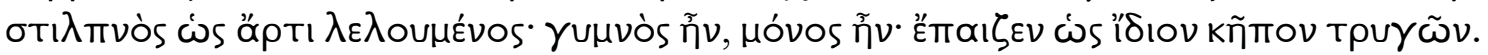

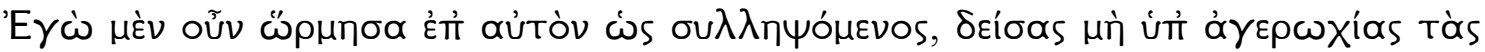

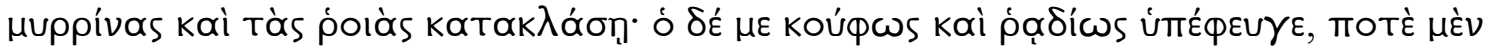

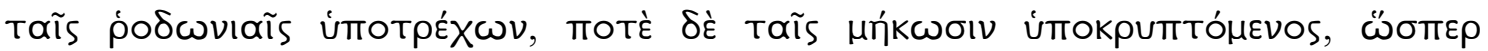

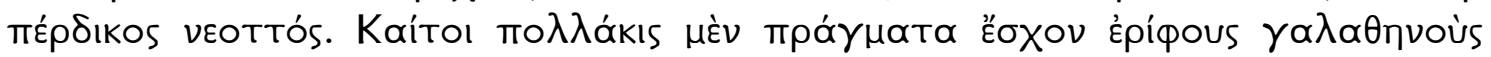

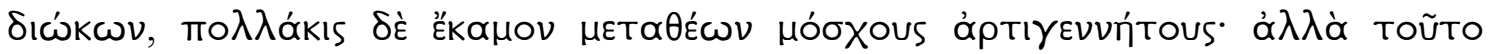

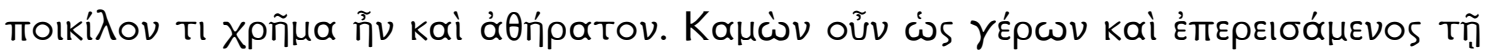

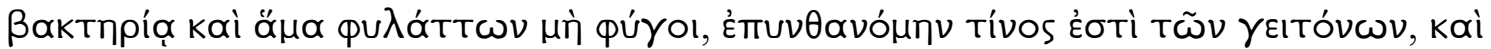

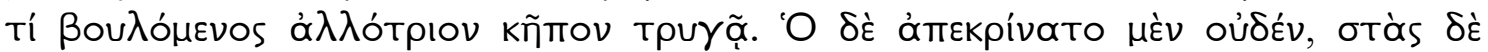

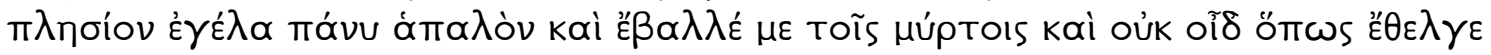

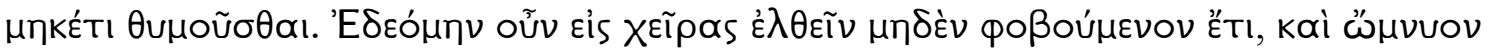

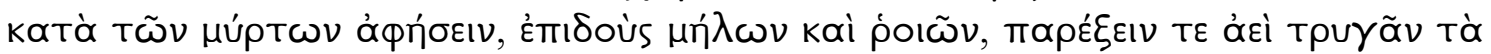

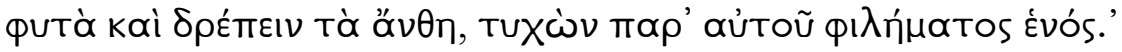

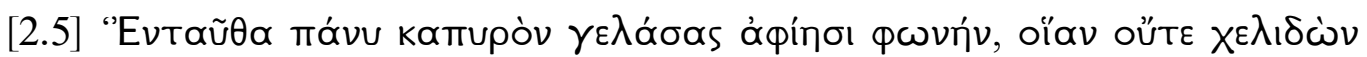

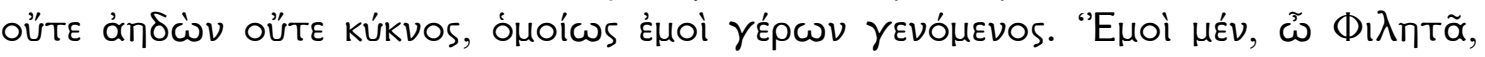


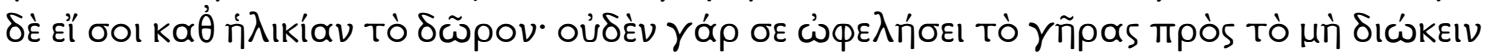

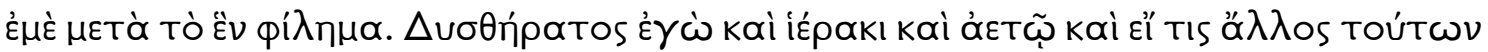

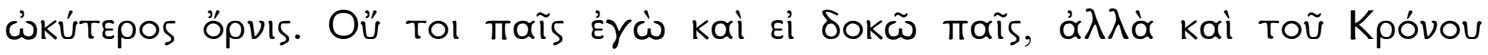

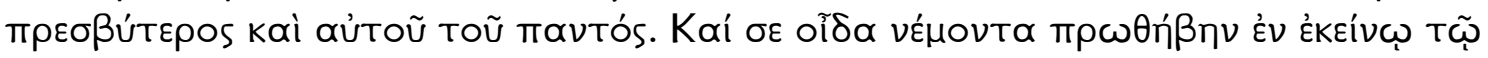

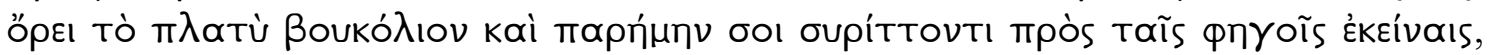

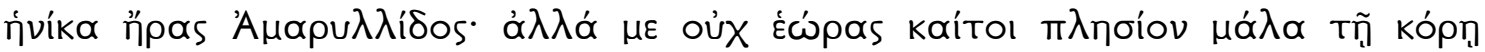

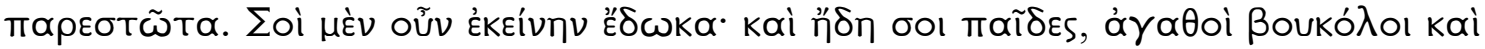

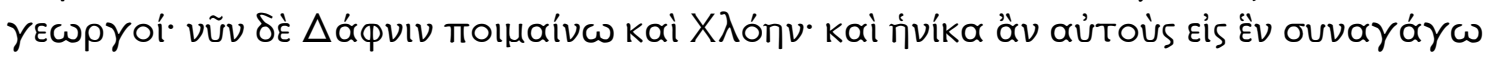




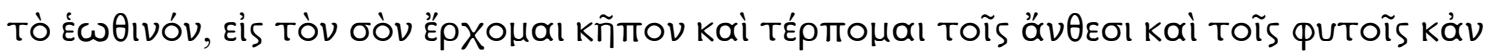

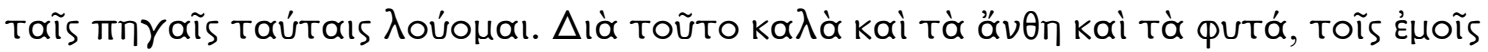

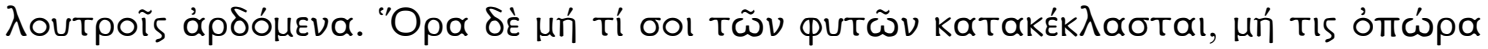

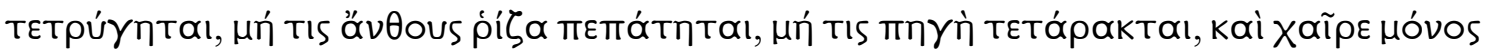

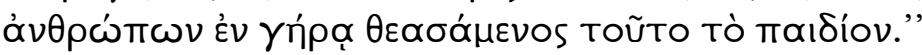

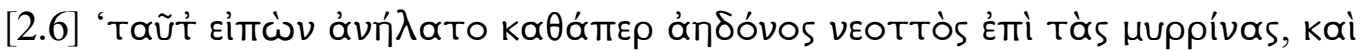

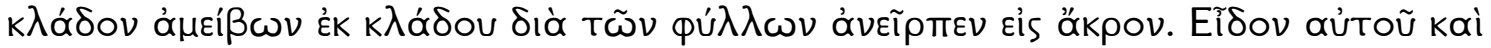

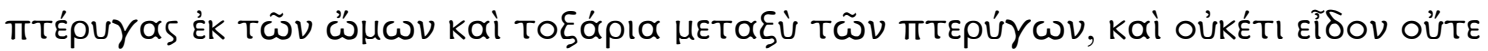

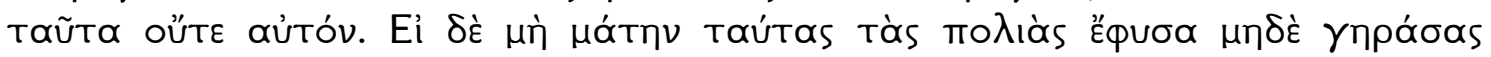

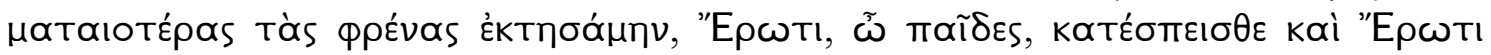
ن் $\mu \tilde{\omega} \nu \mu \varepsilon \dot{\lambda} \varepsilon \varepsilon . '$

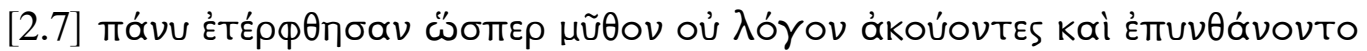

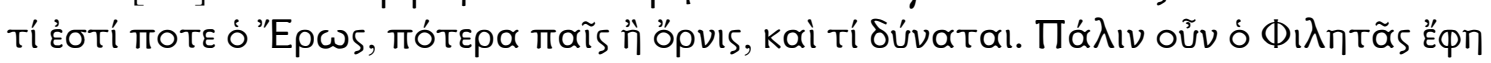

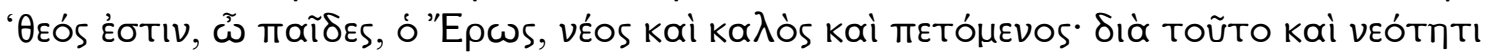

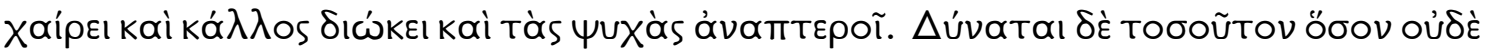

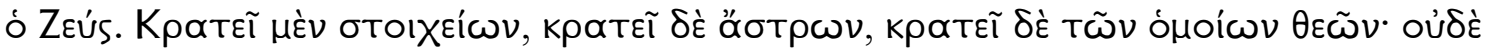

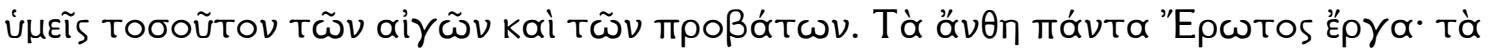

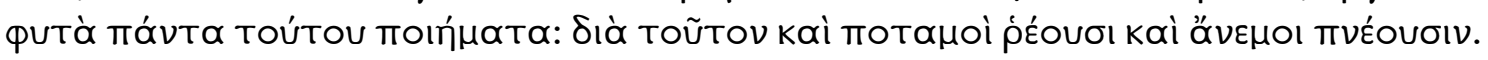

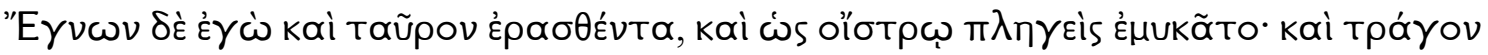

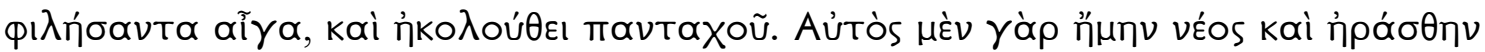

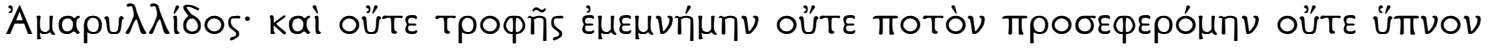

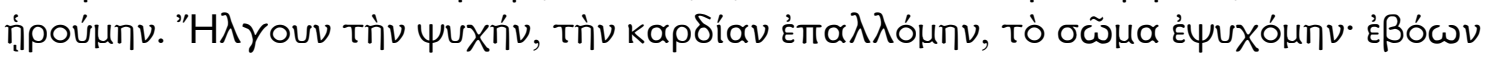

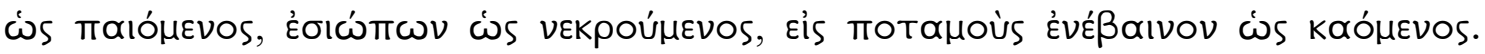

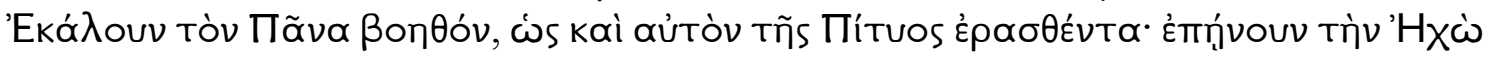

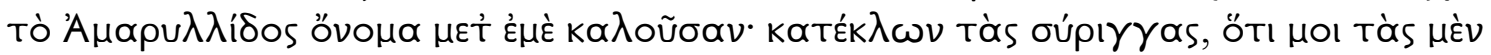

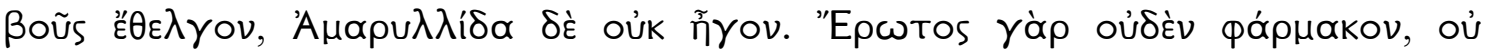

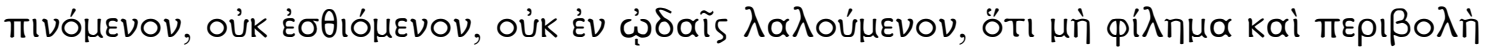

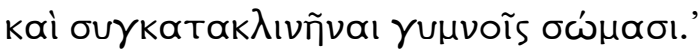

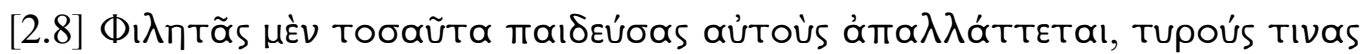

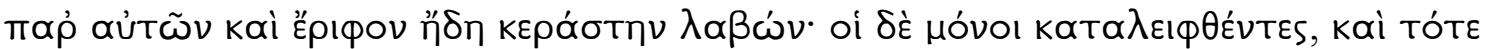

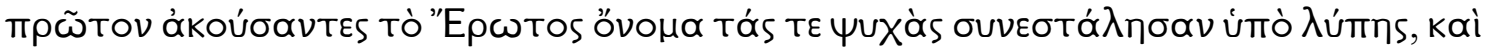

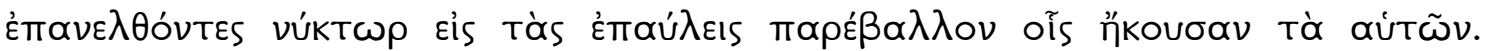

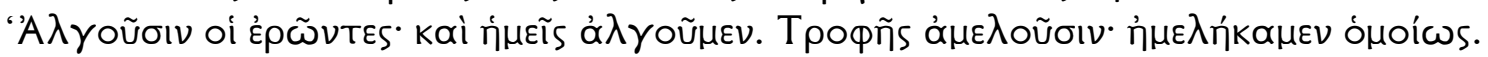

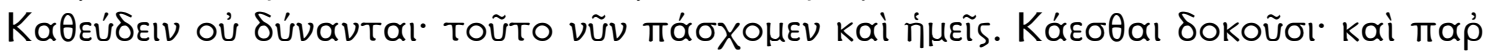

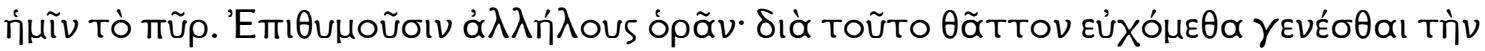

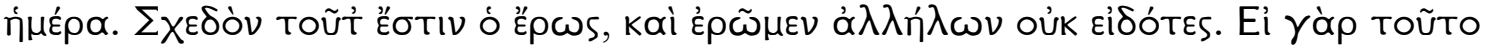

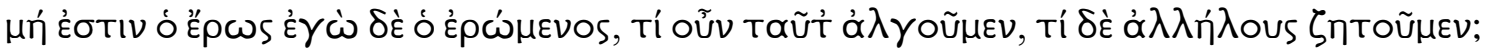

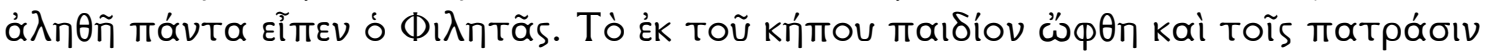

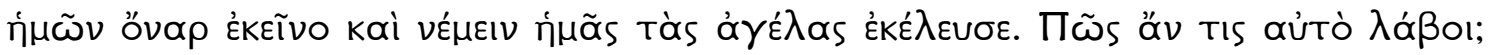

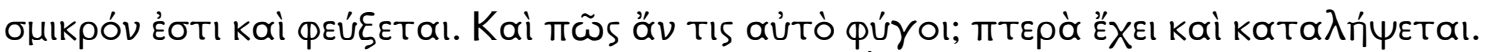

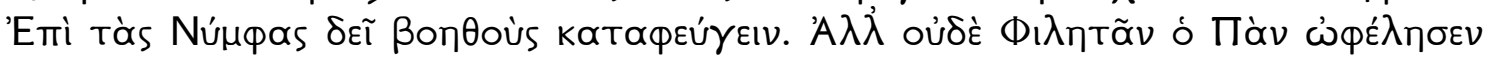

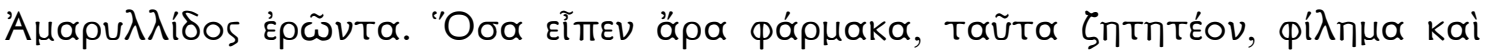

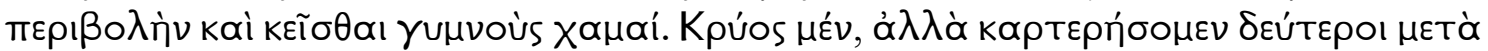
$\Phi_{1} \lambda \eta \tau \tilde{\alpha} v . '$

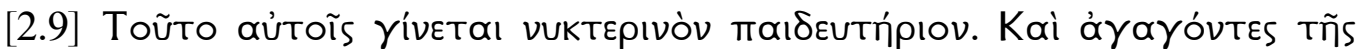

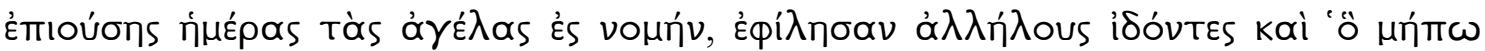

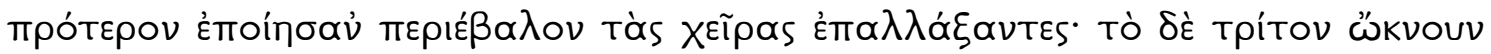

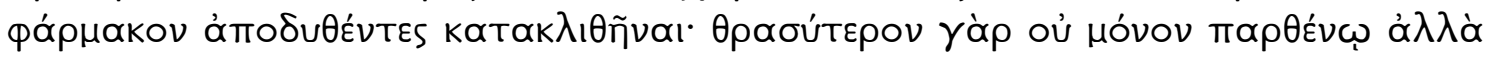




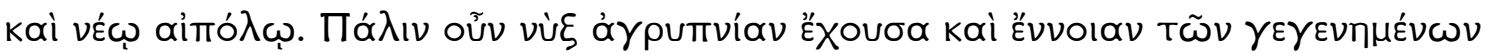

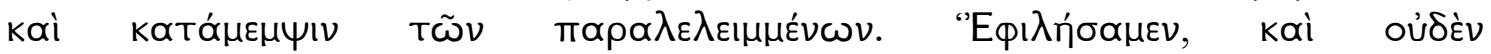

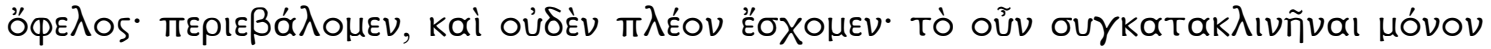

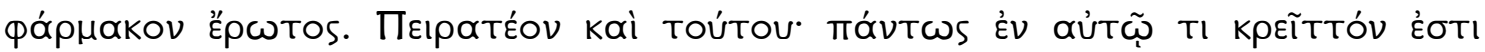
фìńmatos.'

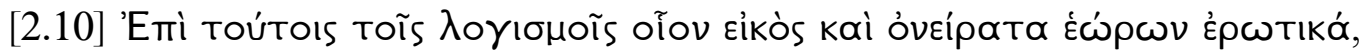

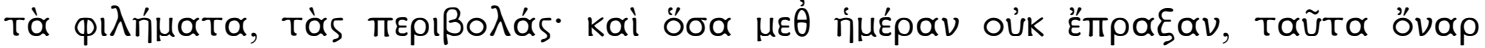

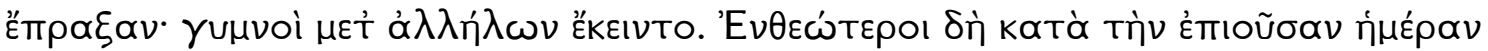

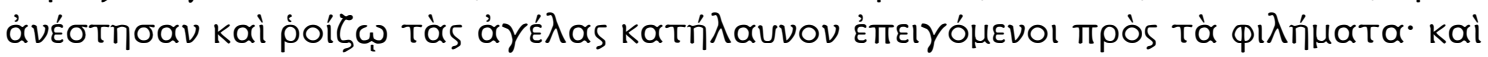

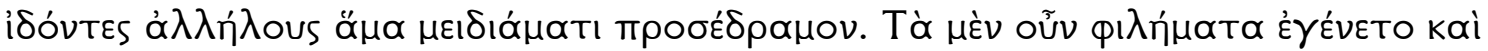

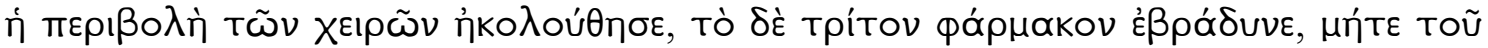

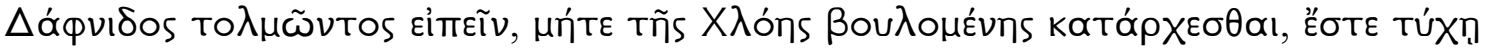

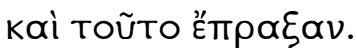

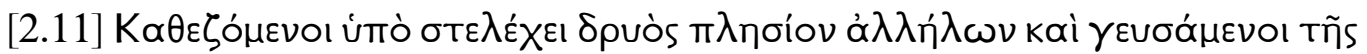
Év фı

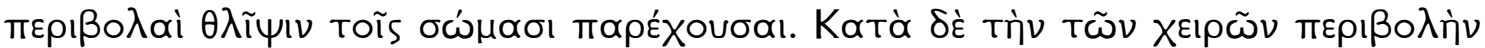

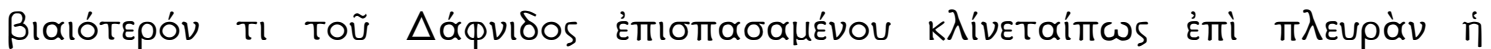

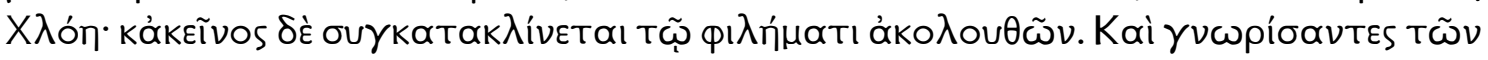

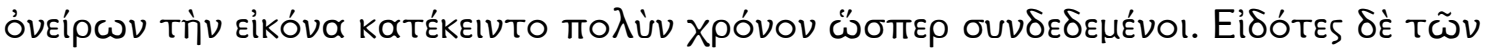

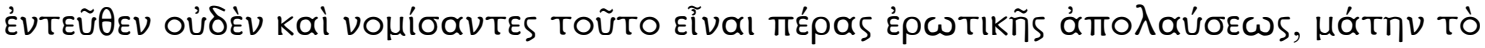

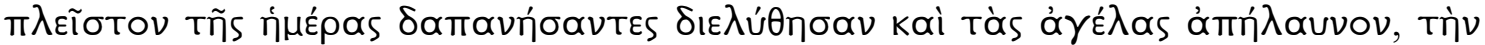

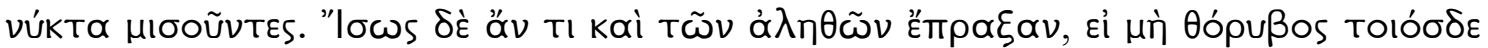

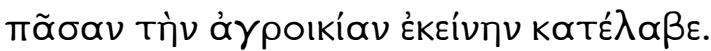

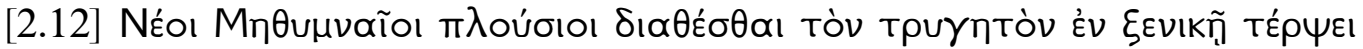

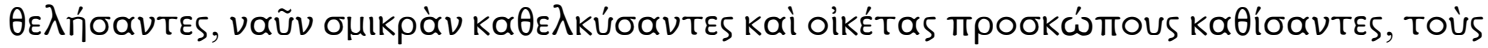

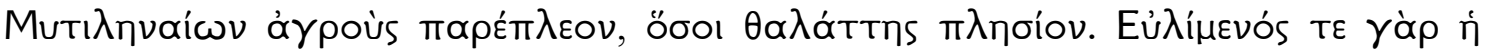

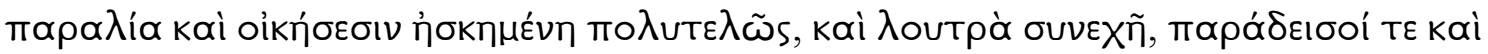

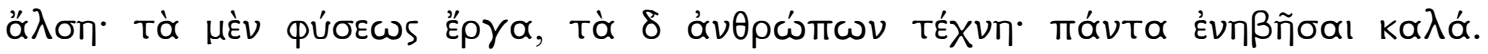

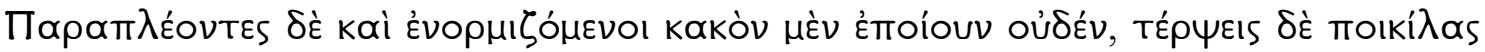

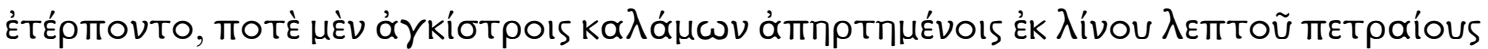

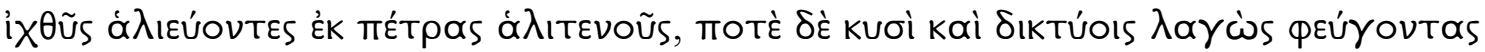

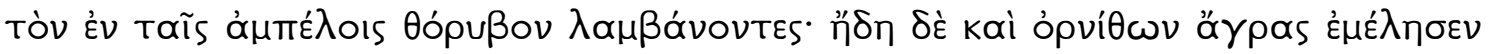

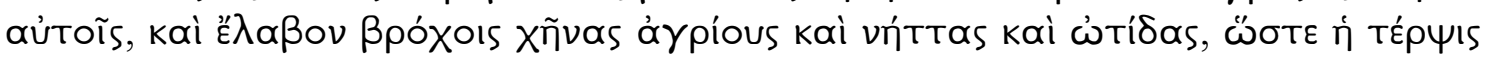

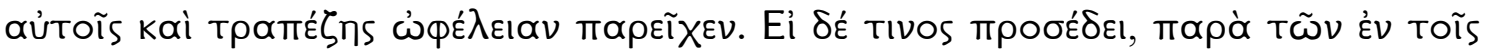

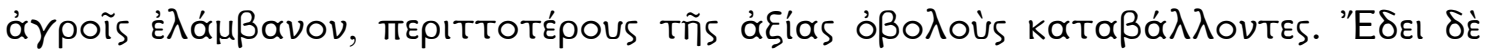

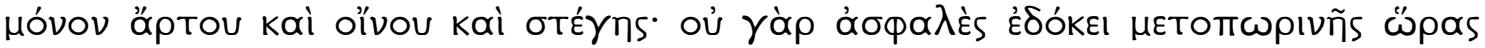

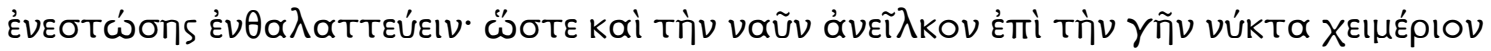

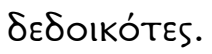

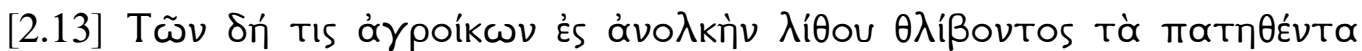

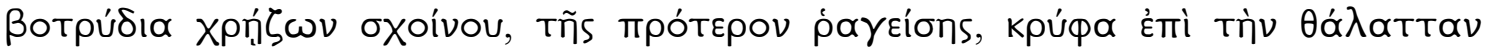

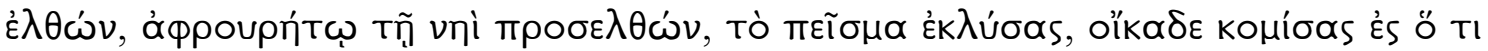

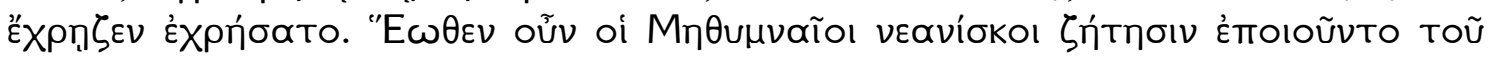

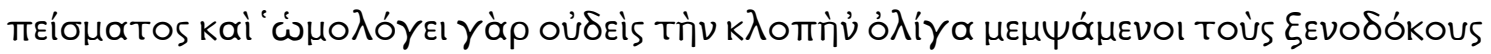

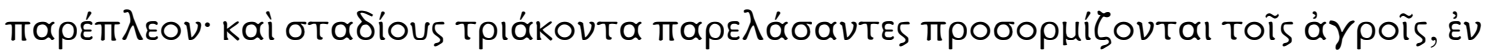

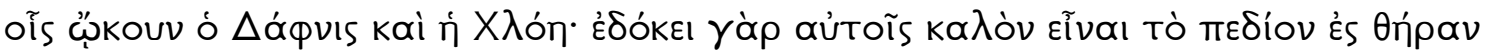

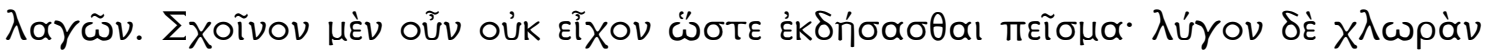

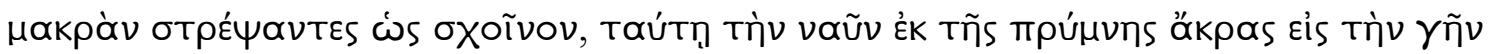

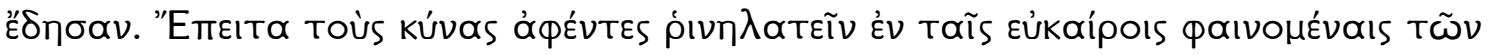




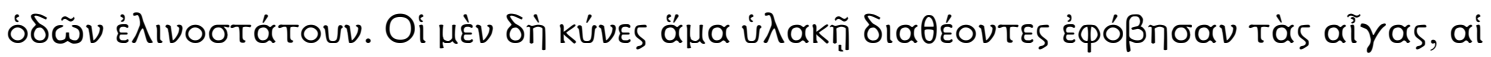

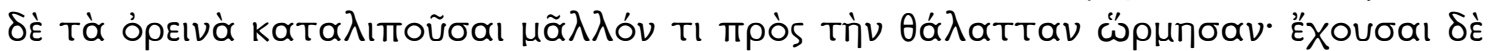

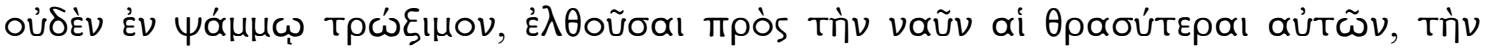

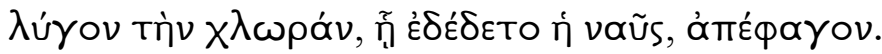

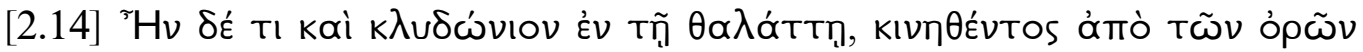

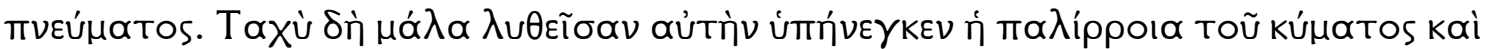

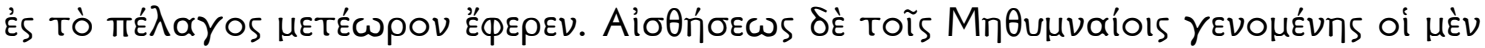

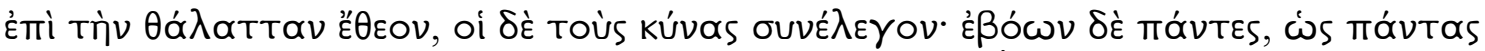

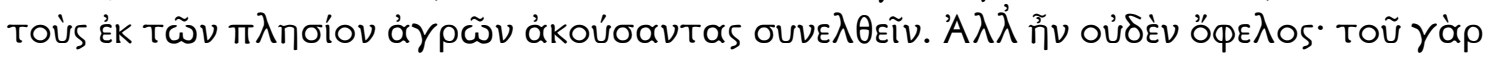

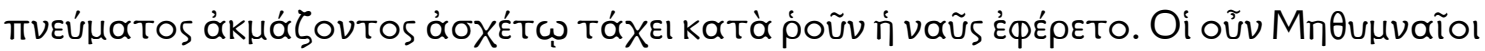

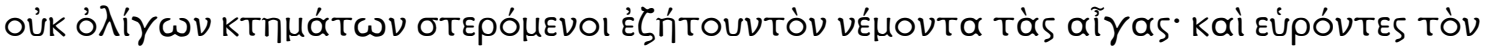

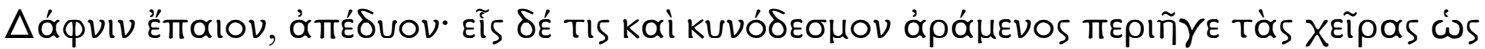

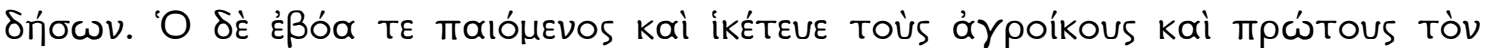

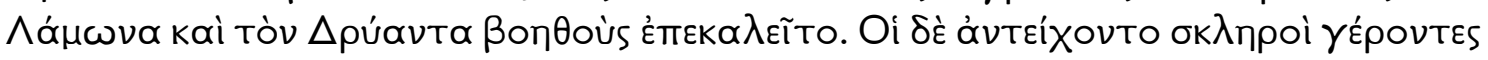

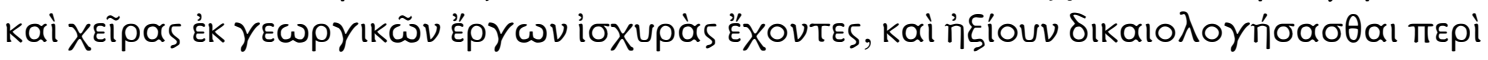

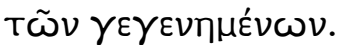

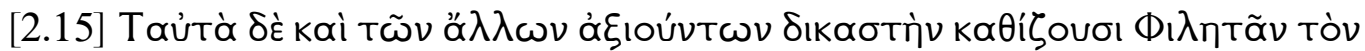

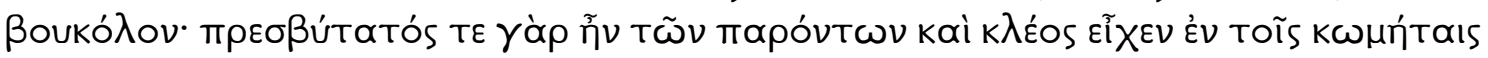

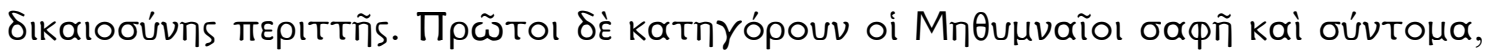

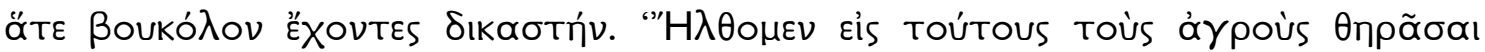

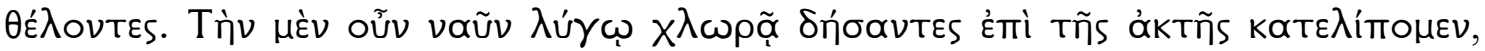

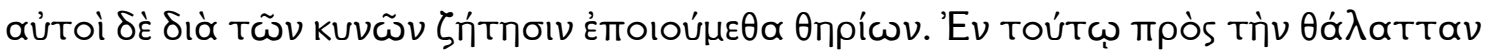

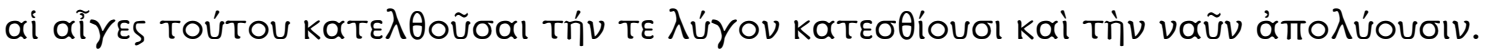

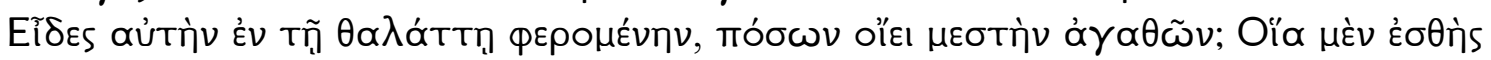

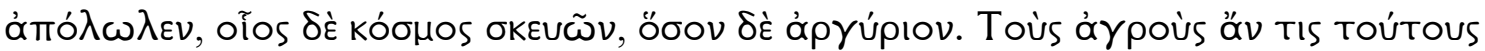

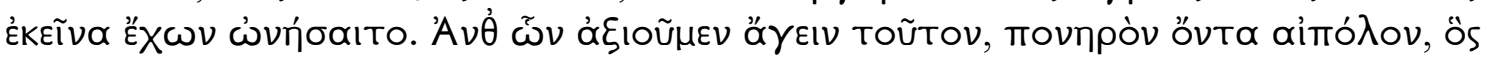

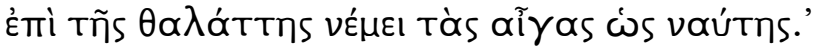

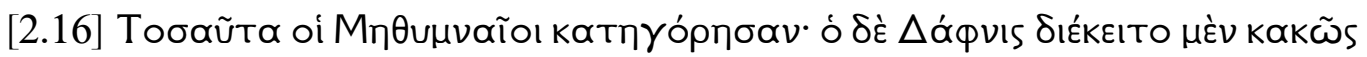

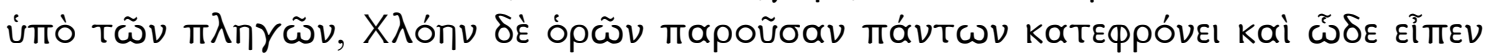

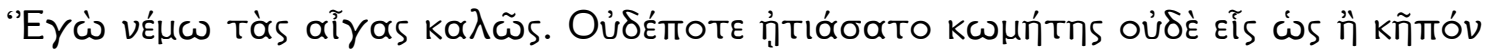

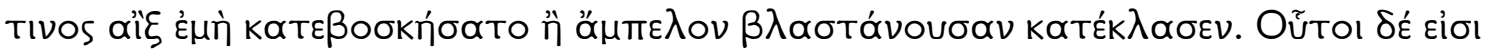

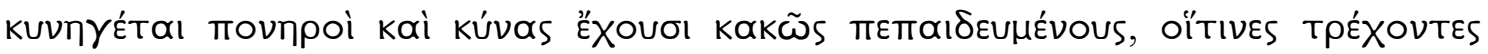

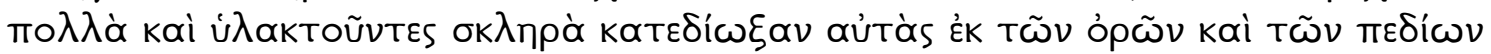

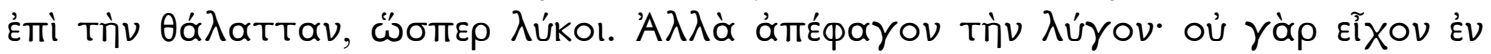

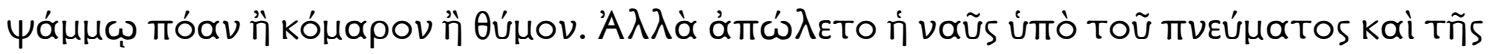

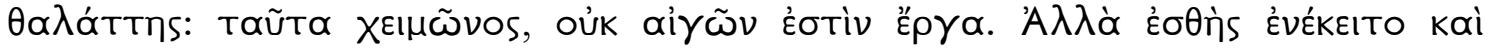

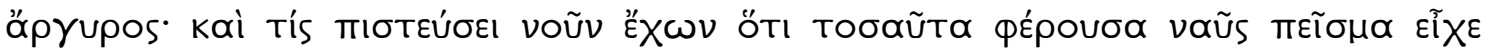

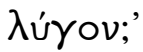

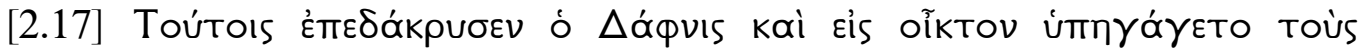

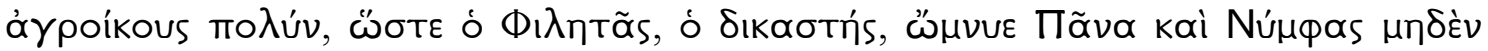

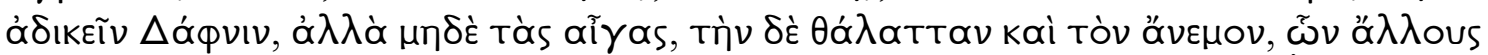

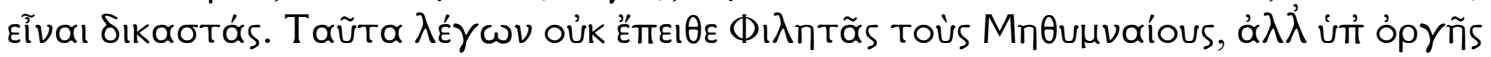

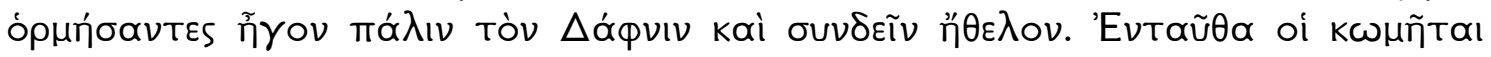

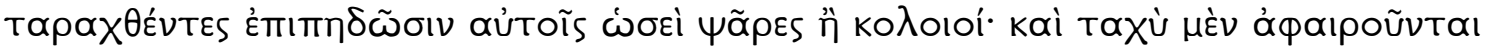

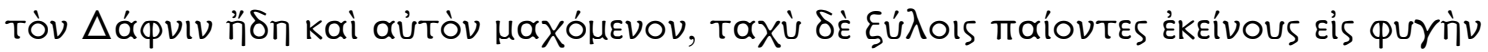

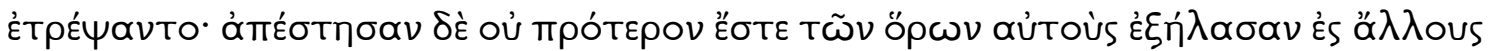
àypoús. 


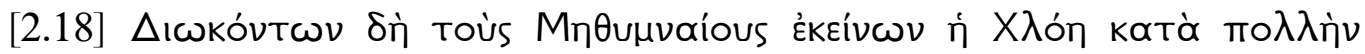

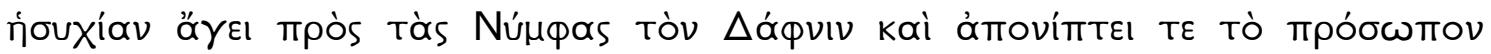

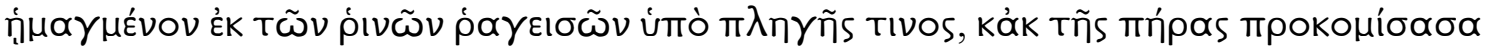

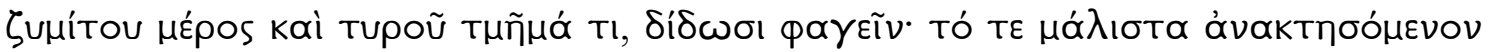

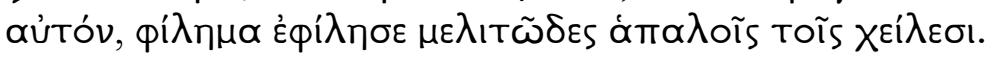

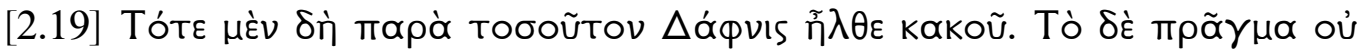

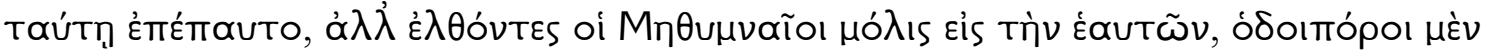

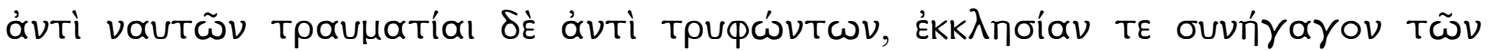

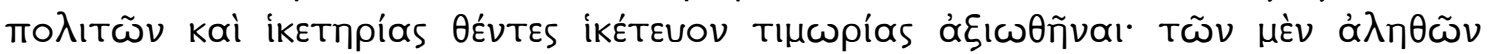

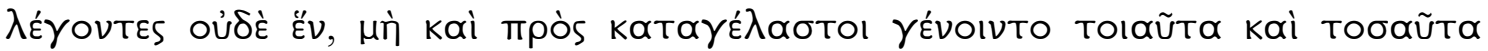

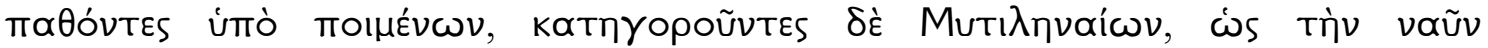

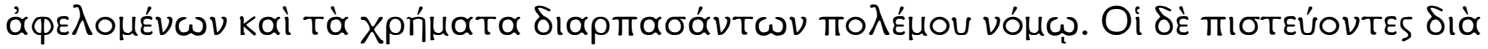

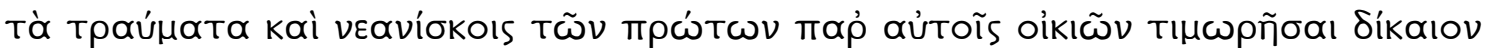

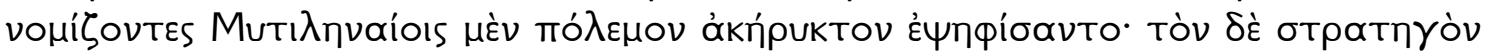

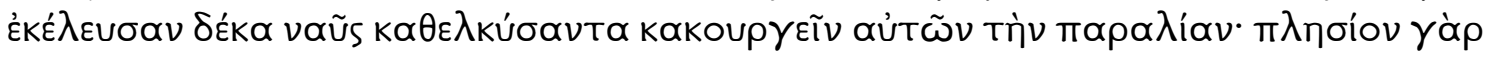

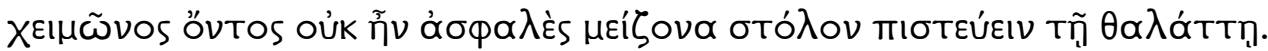

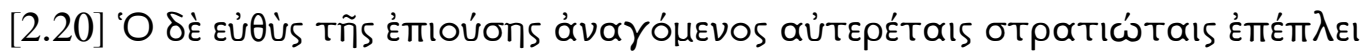

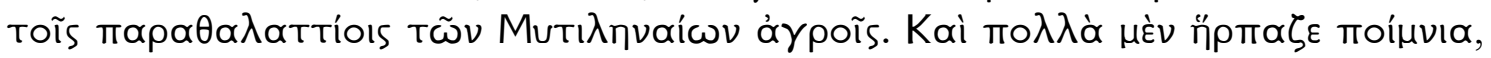

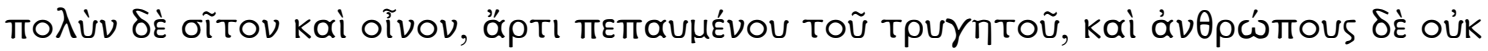

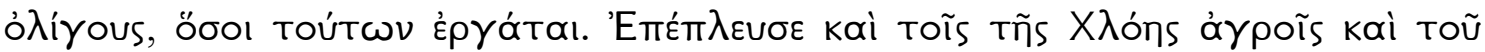

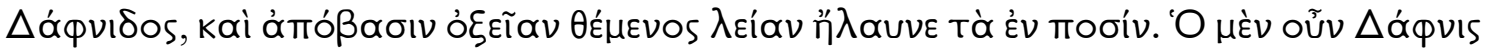

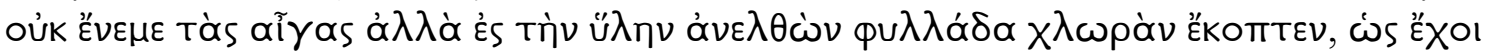

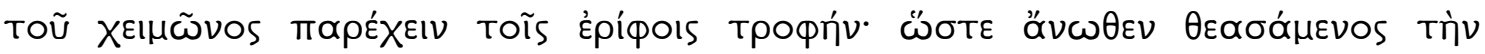

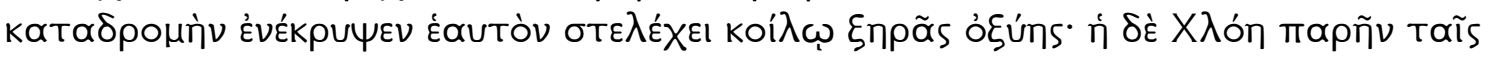

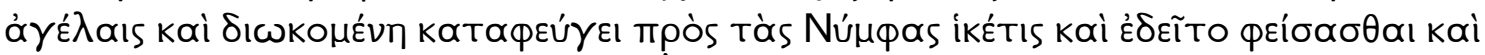

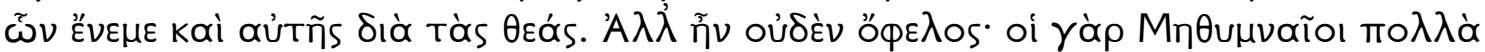

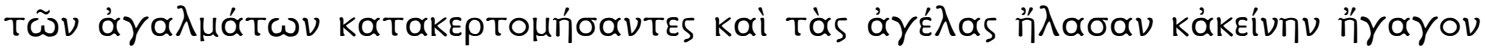

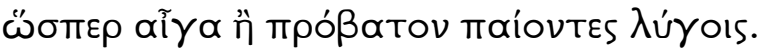

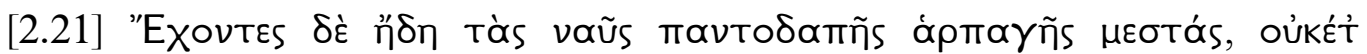

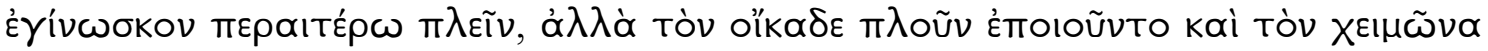

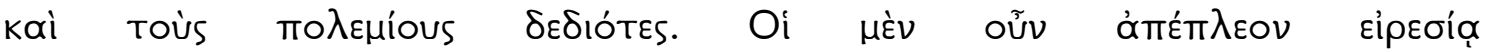

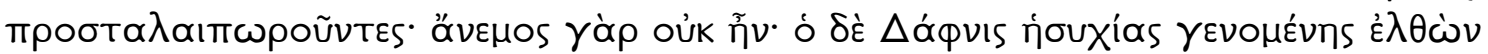

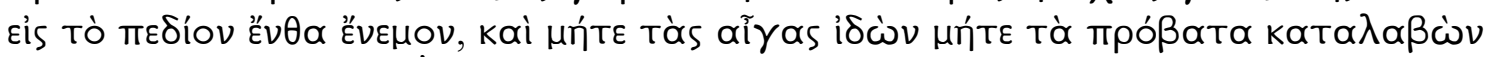

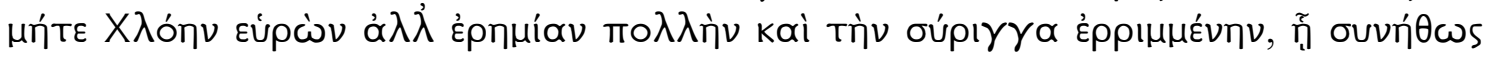

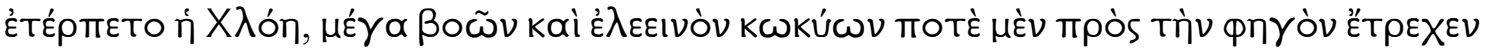

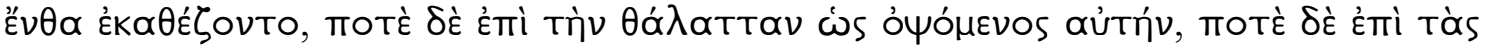

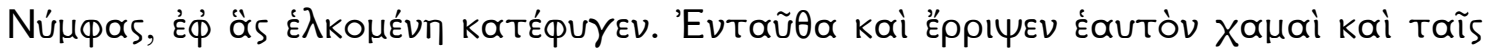

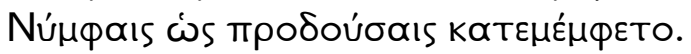

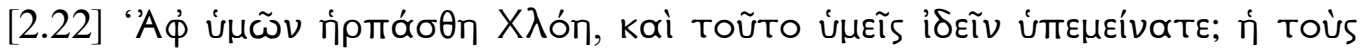

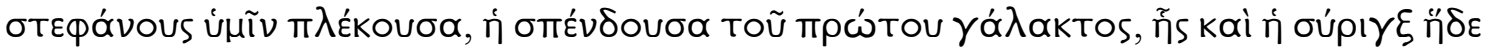

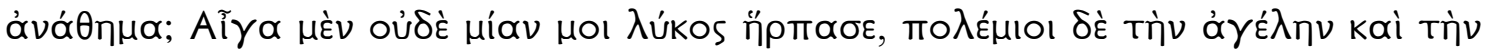

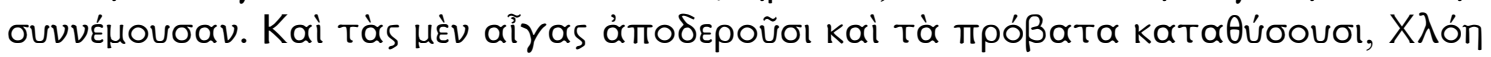

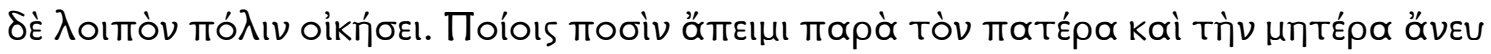

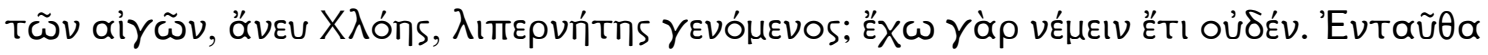

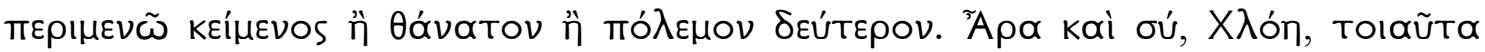

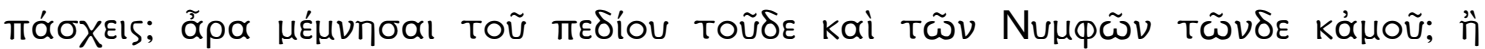

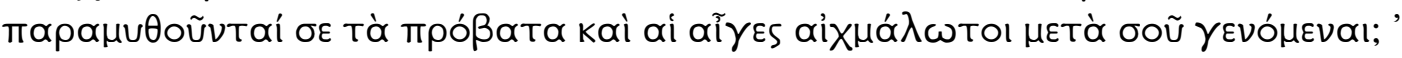




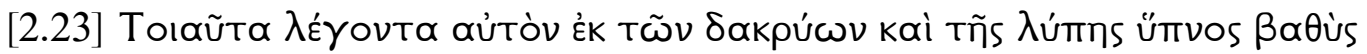

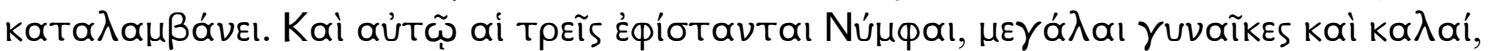

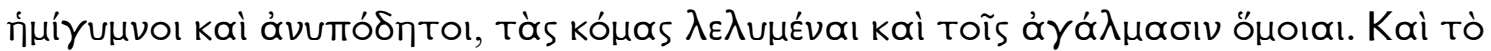

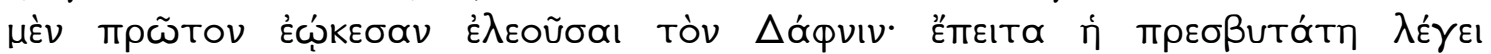

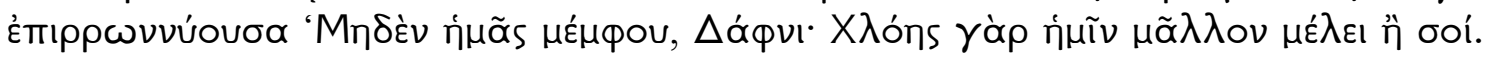

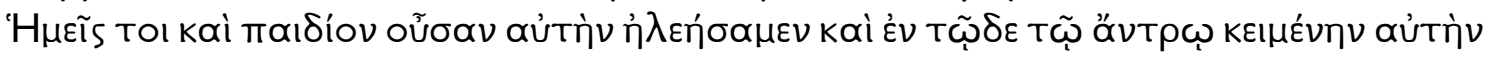

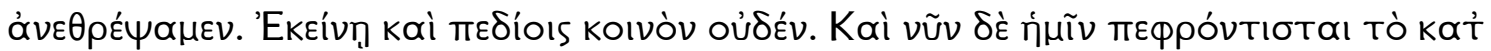

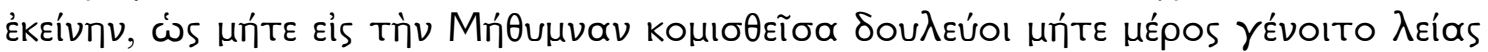

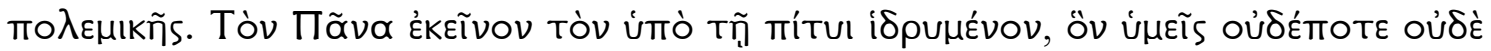

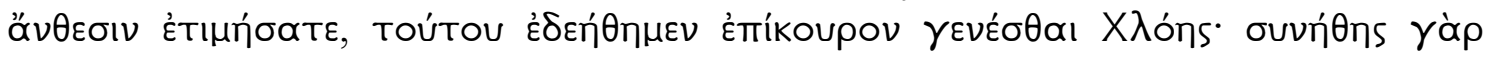

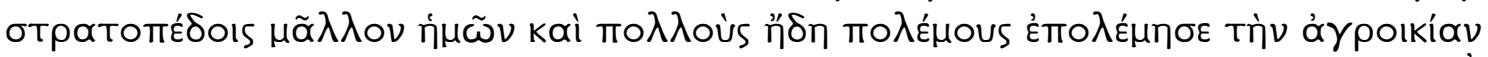

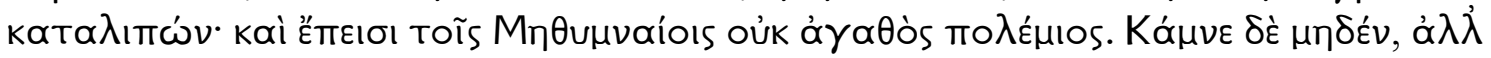

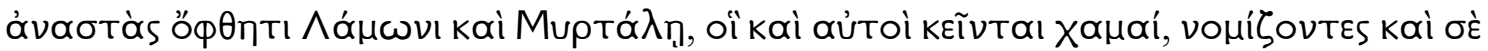

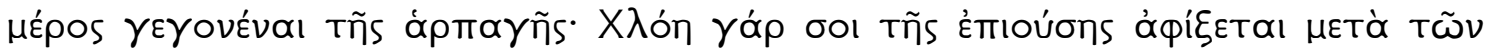

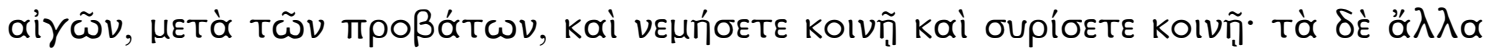

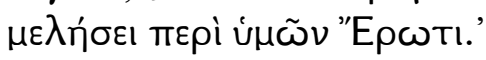

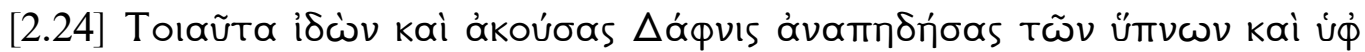

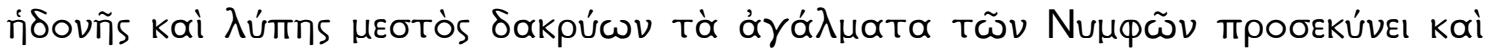

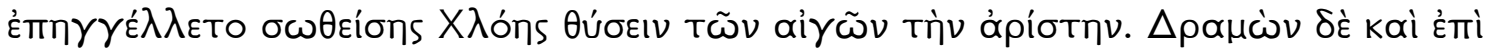

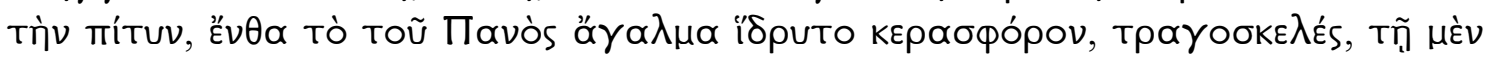

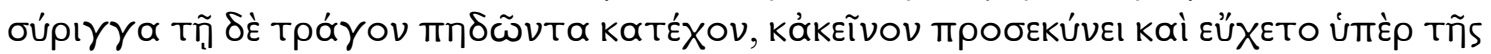

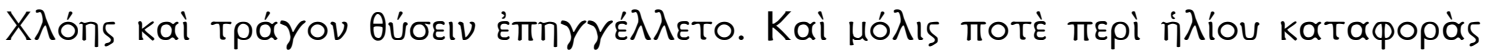

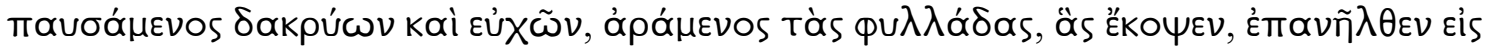

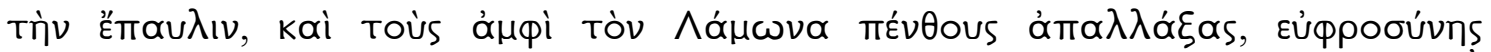

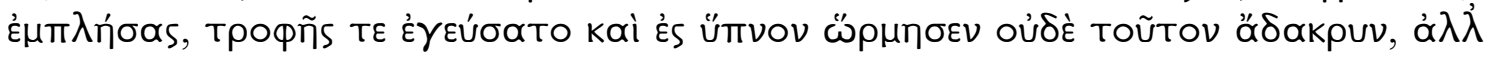

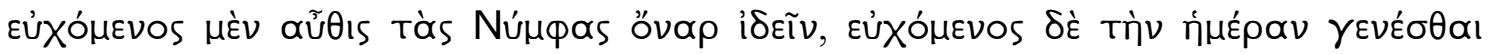

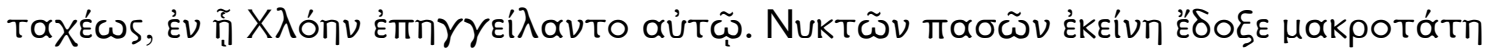

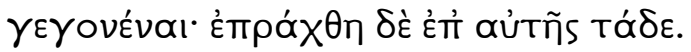

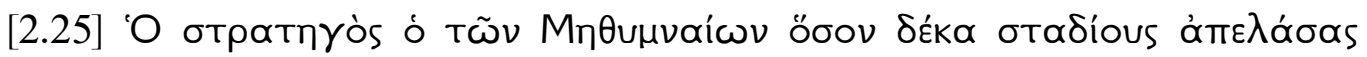

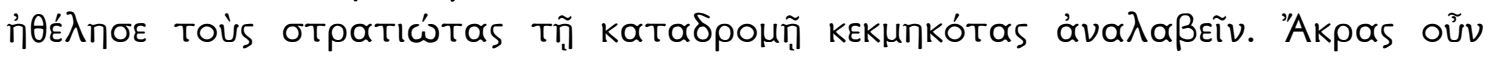

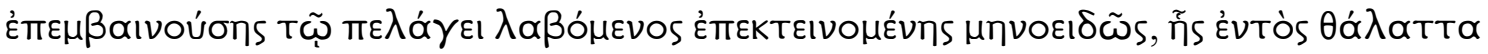

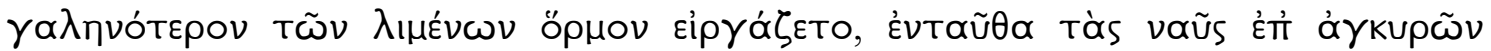

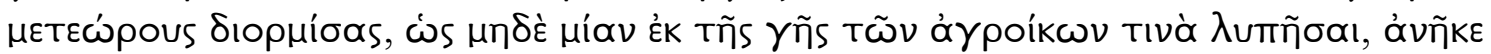

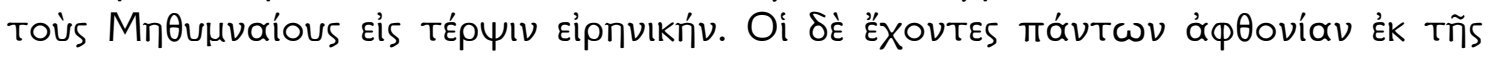

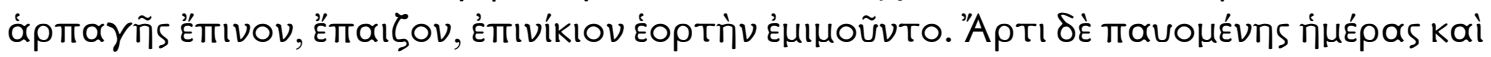

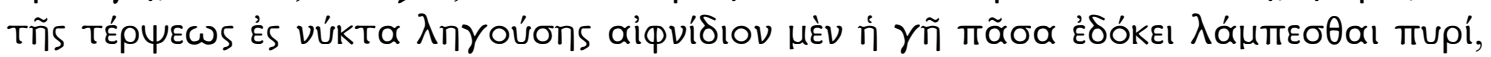

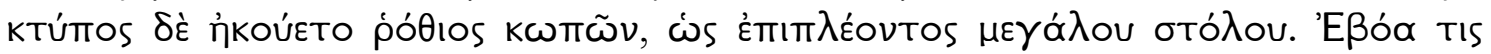

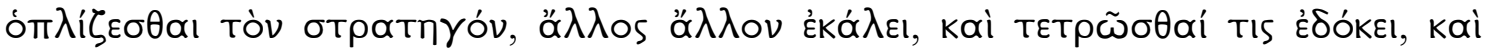

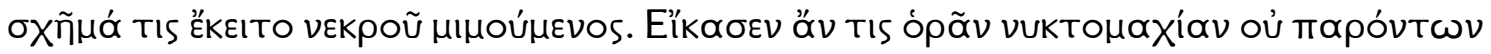
$\pi \circ \lambda \varepsilon \mu i \omega \nu$.

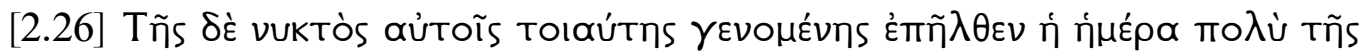
VUKTòs

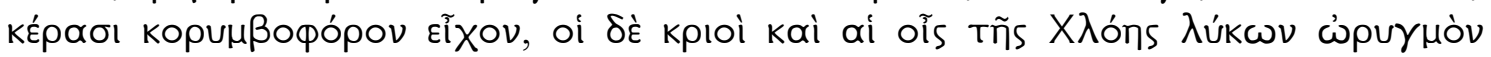

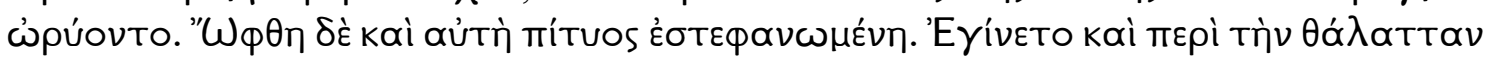

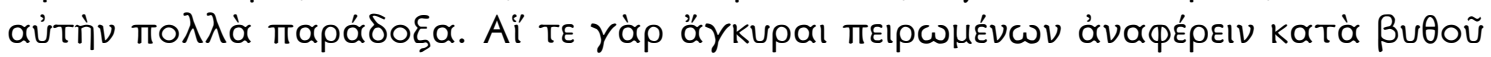

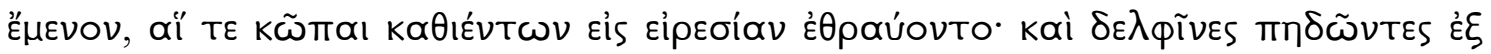

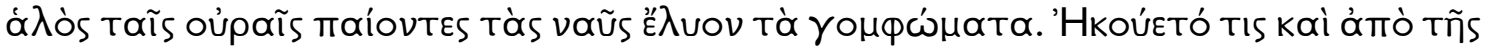

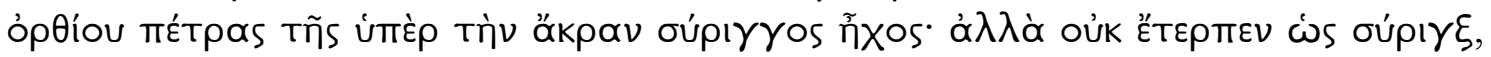




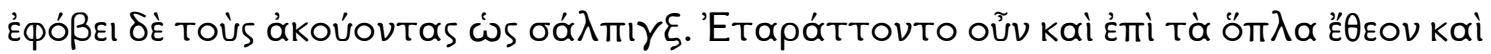

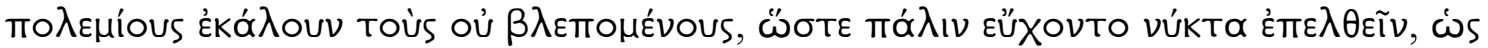

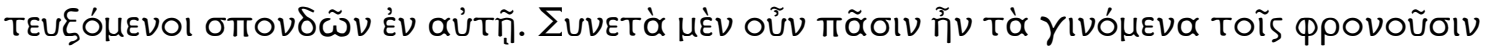

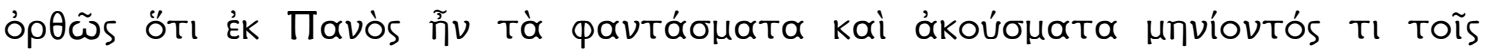

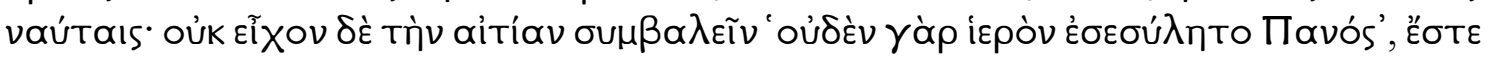

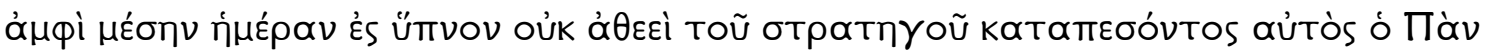

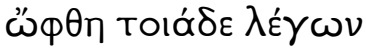

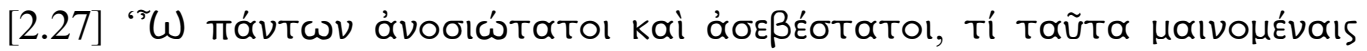

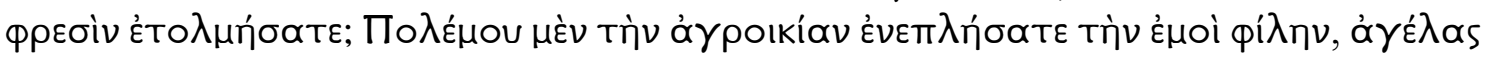

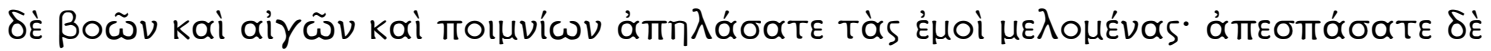

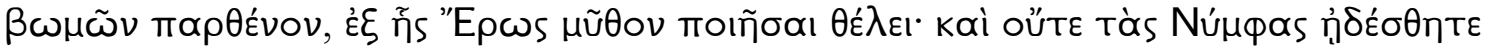

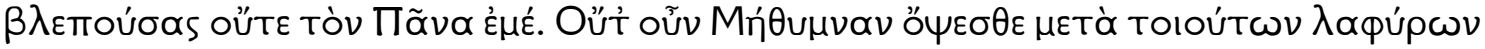

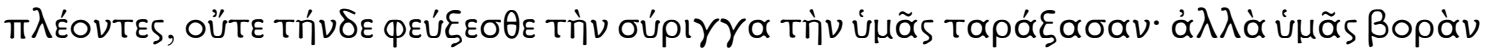

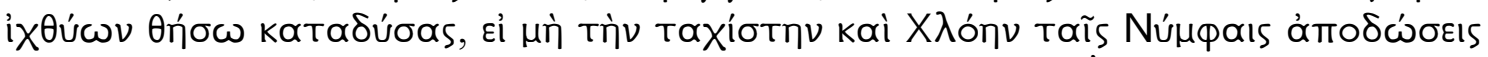

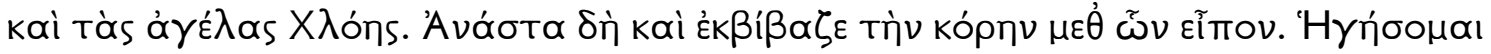

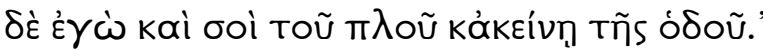

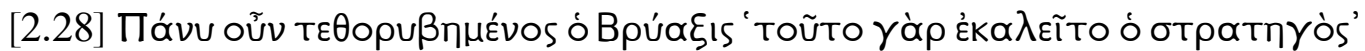

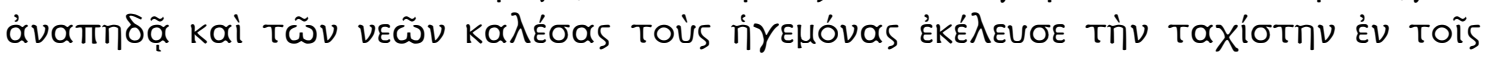

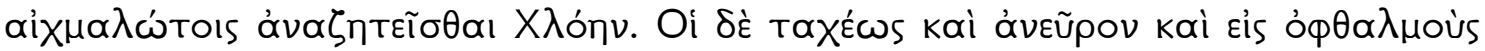

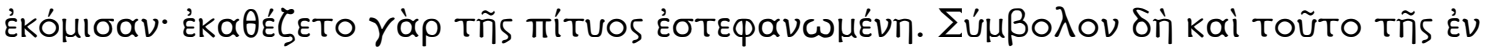

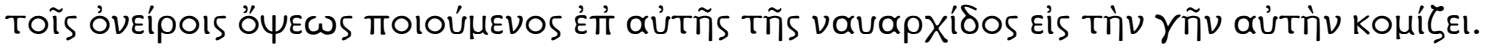

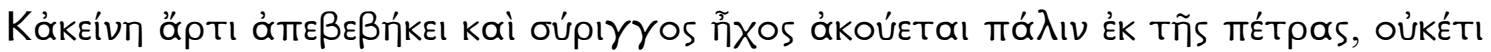

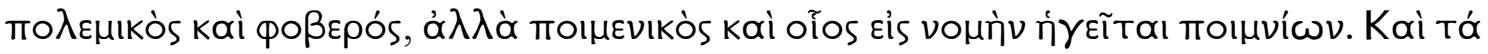

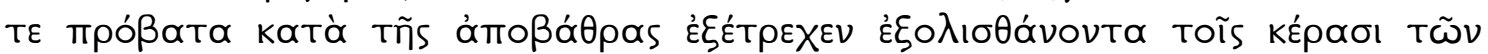

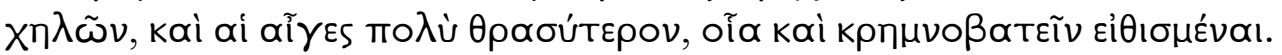

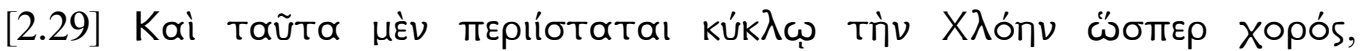

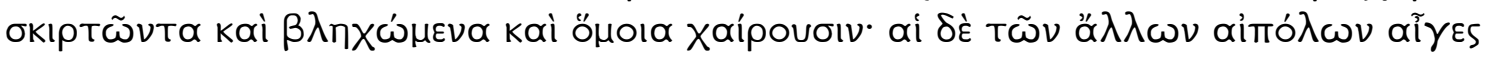

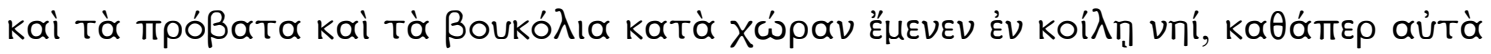

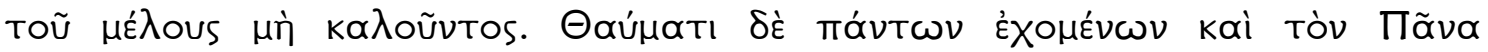

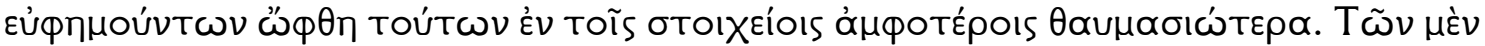

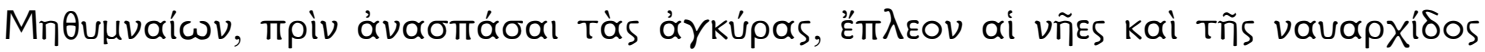

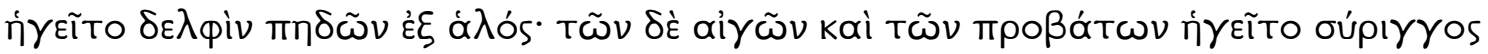

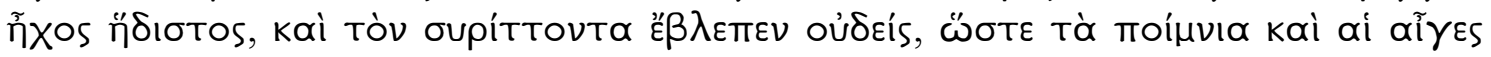

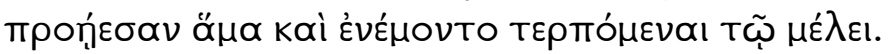

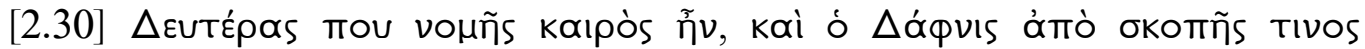

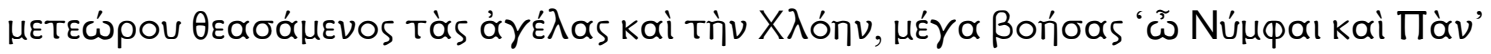

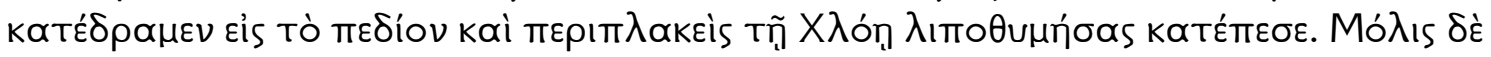

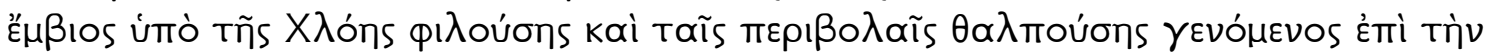

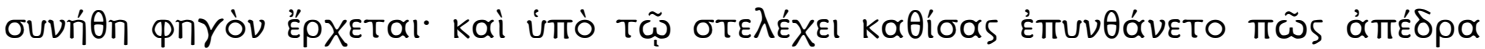

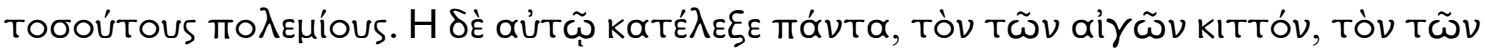

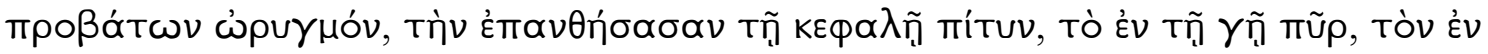

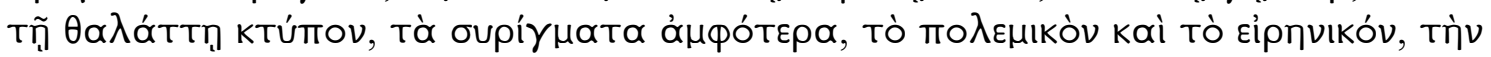

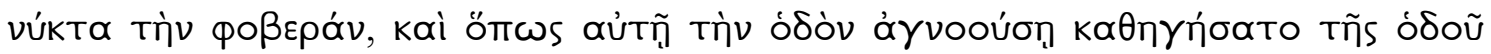

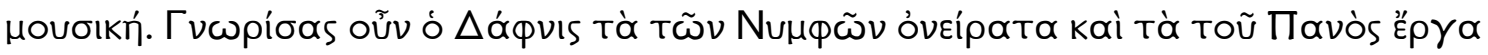

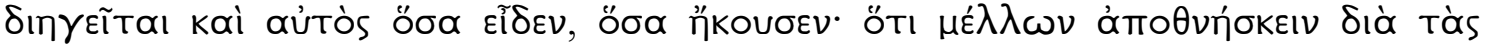

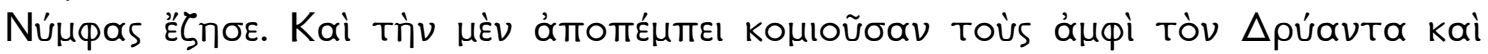

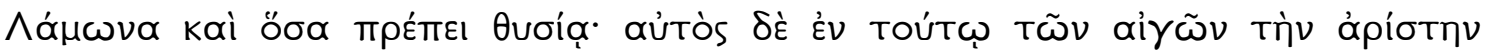

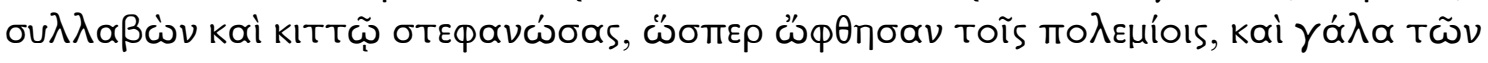




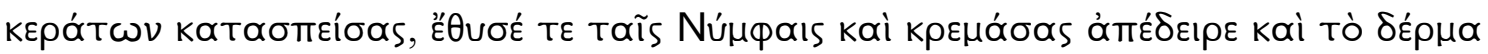
åvéं

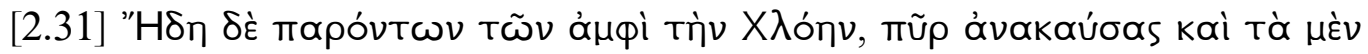

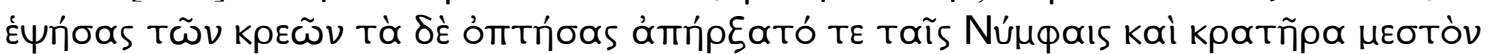

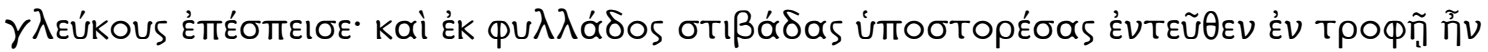

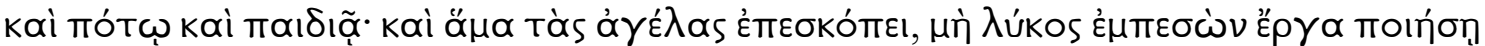

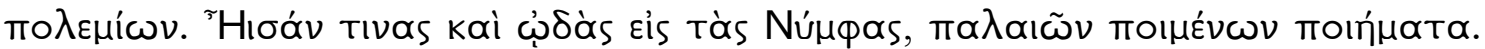

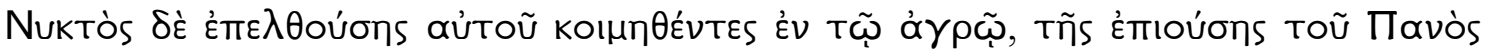

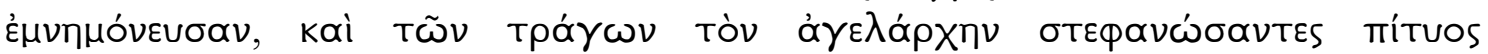

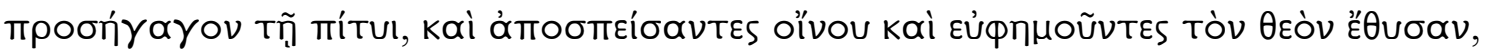

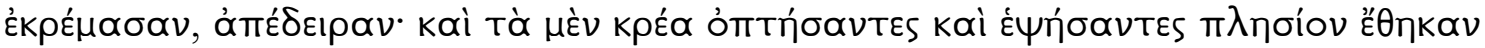

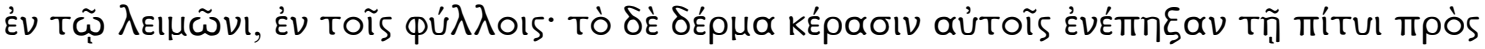

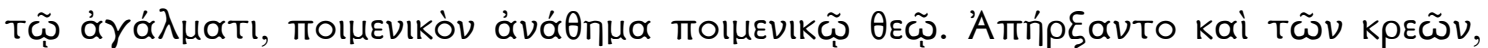
ámé

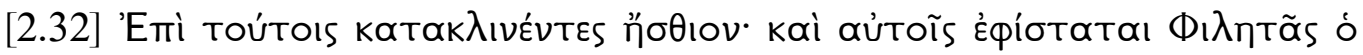

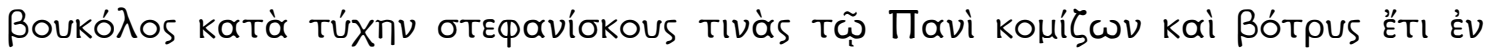

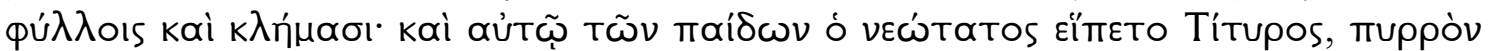

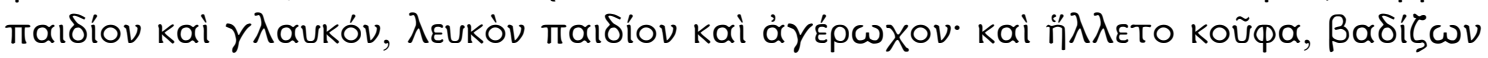

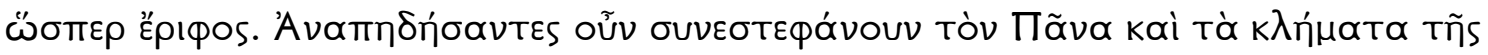

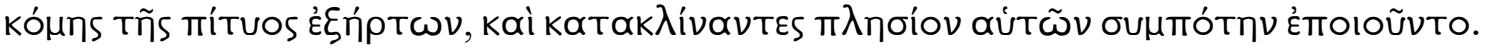

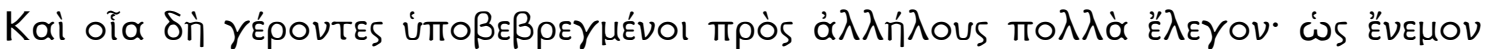

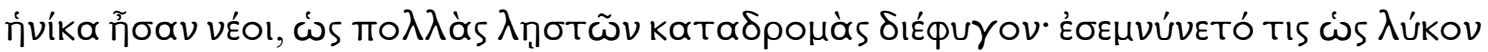

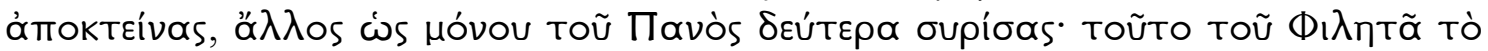

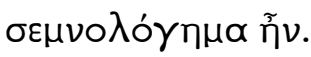

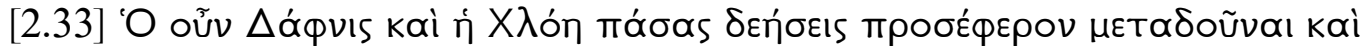

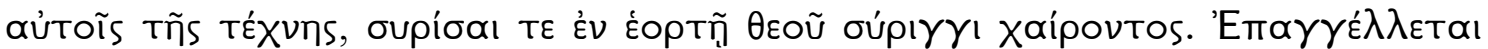

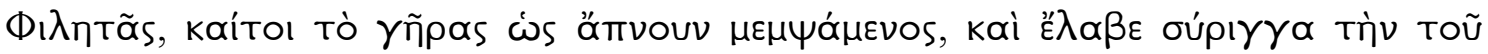

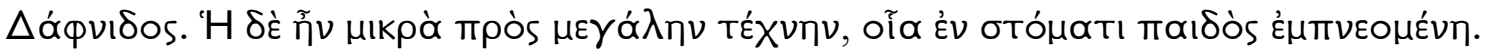

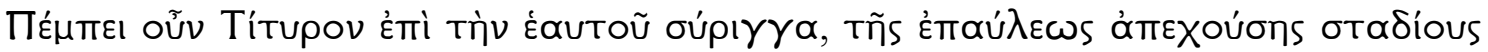

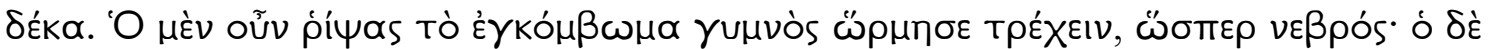

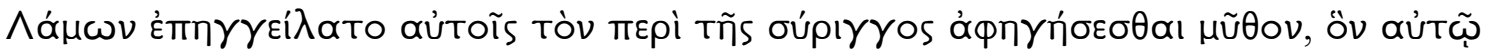

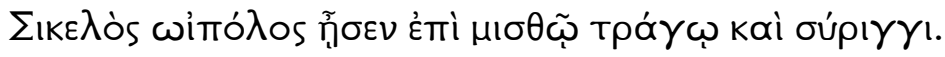

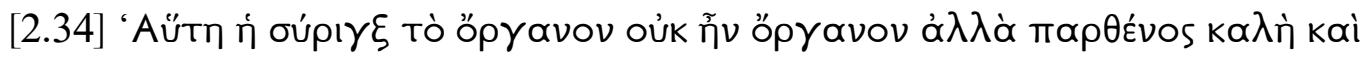

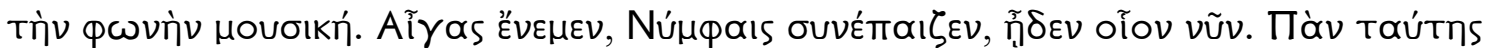

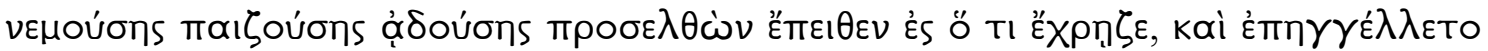

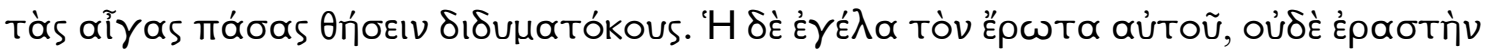

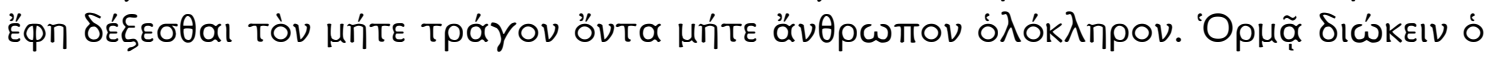

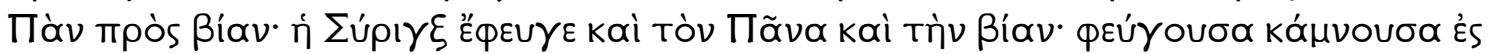

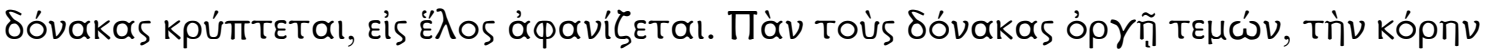

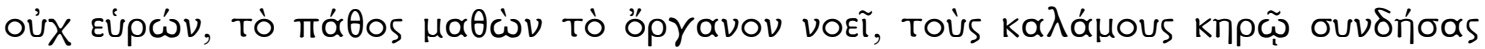

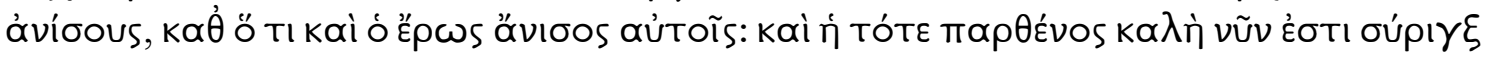
нovoikń.'

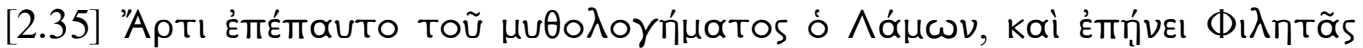

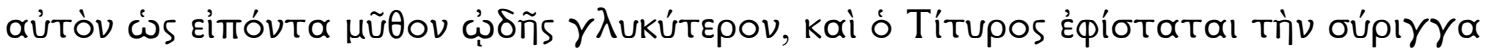

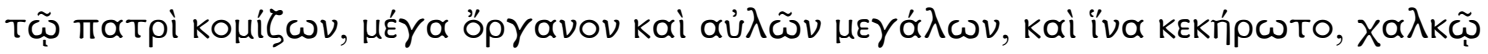

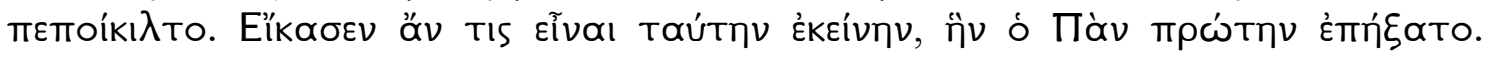

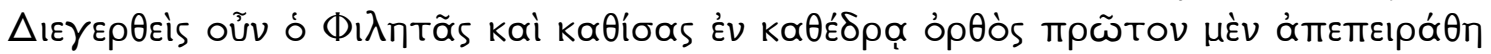

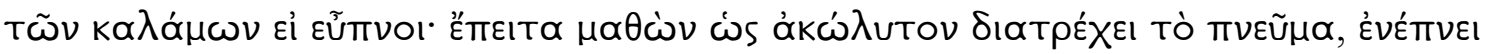




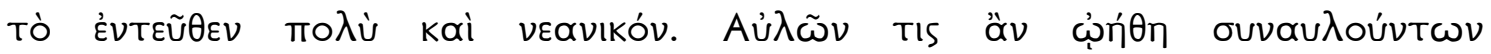

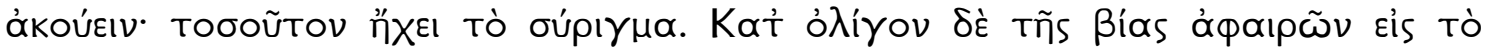

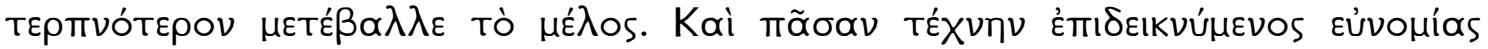

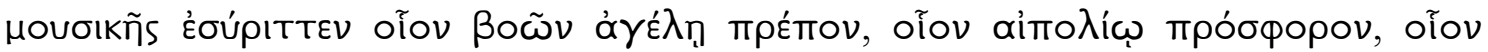

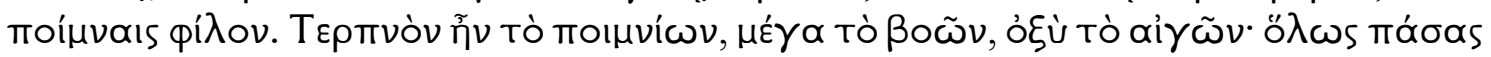

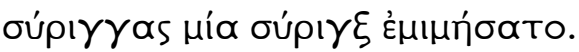

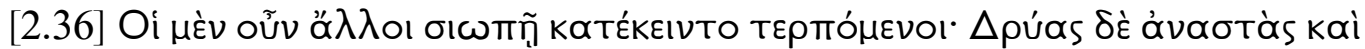

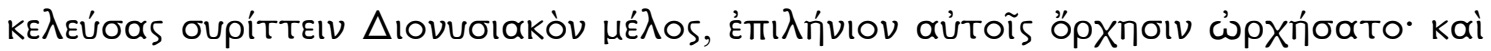

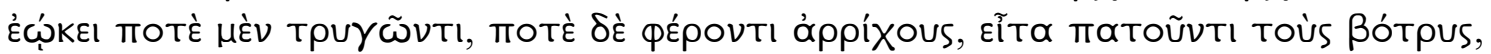

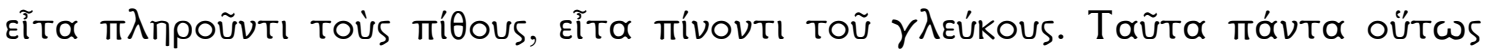

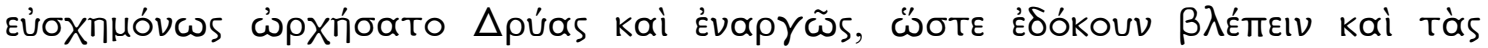

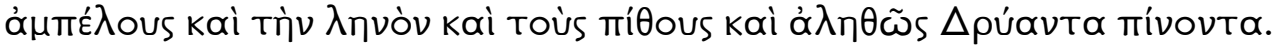

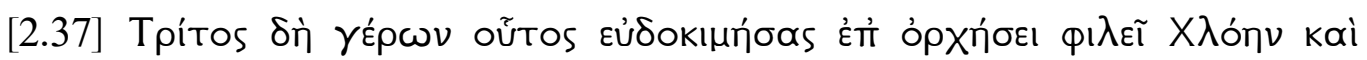

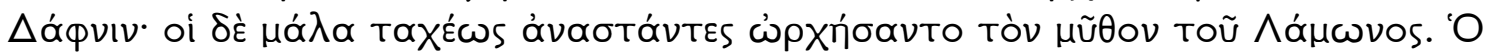

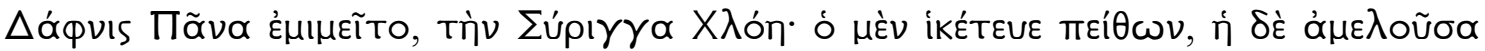

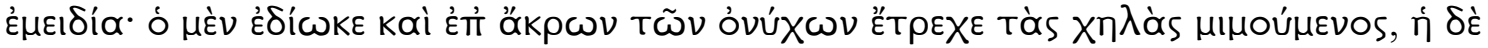

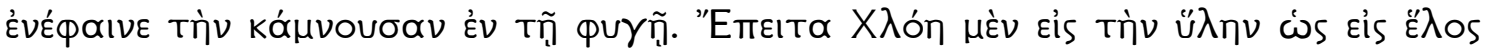

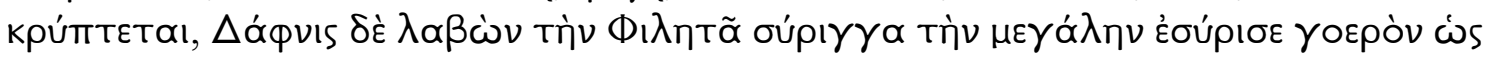

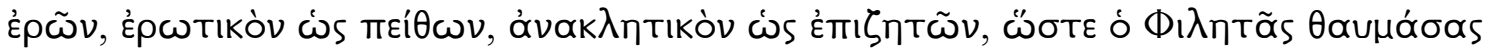

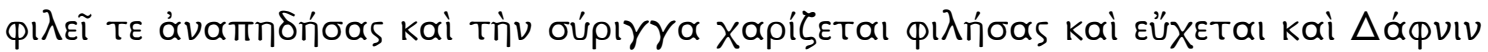

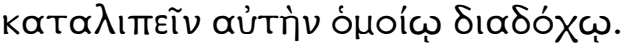

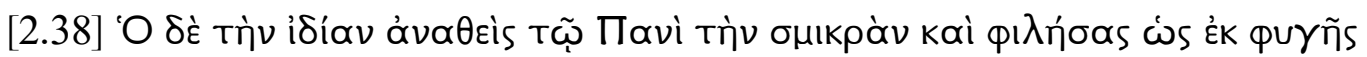

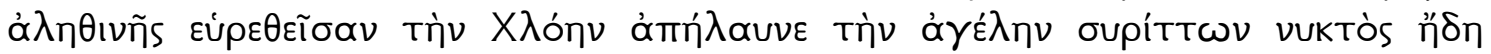

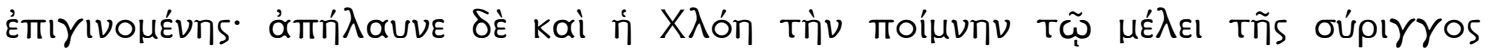

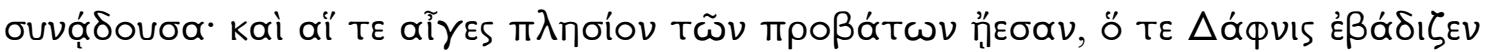

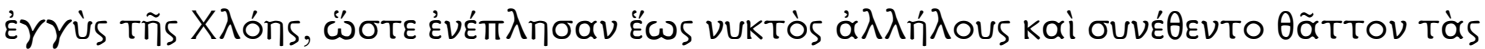

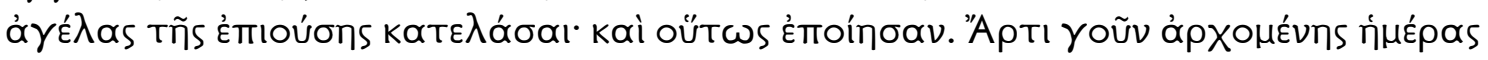

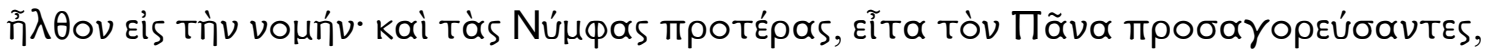

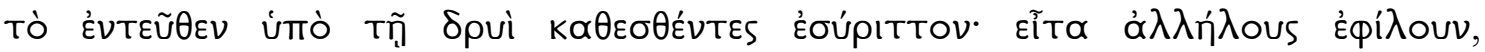

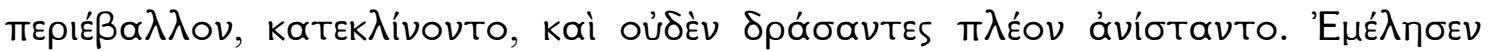

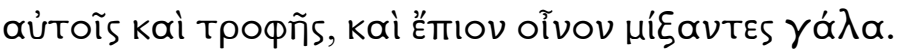

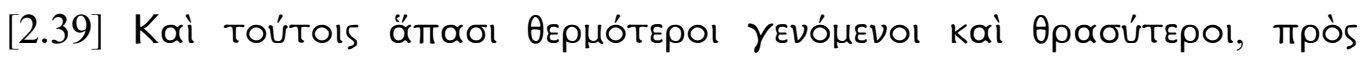

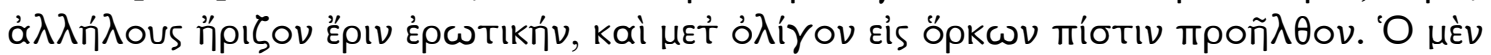

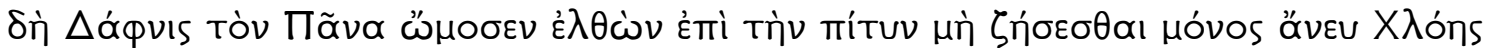

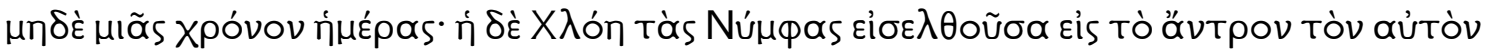

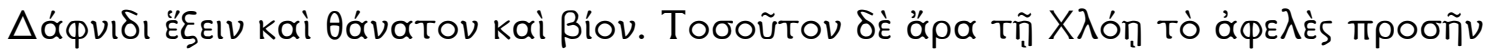

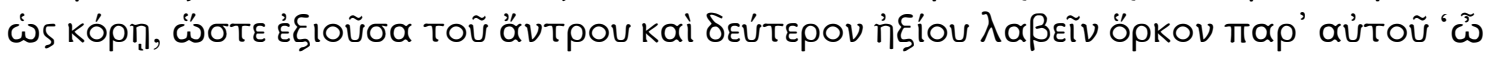

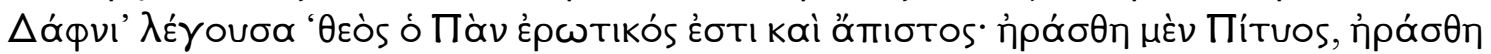

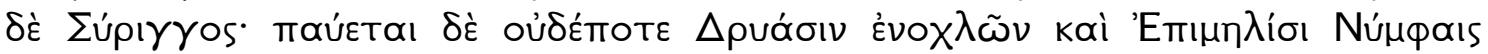

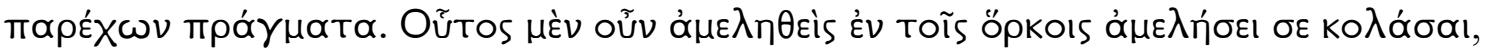

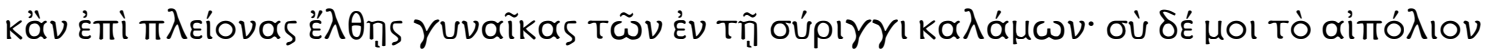

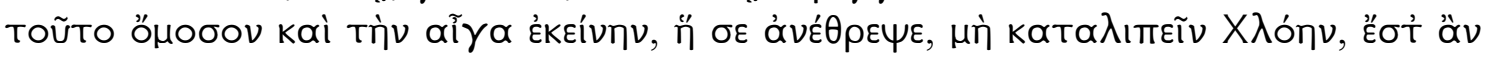

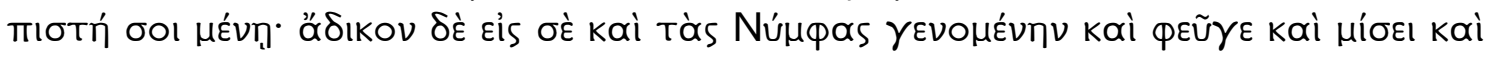

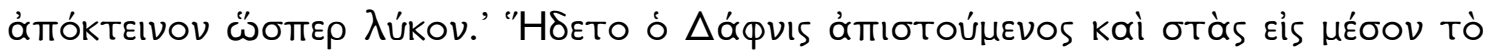

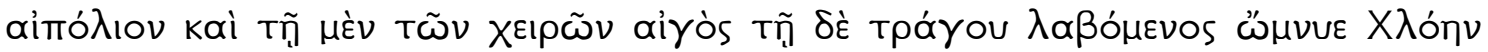

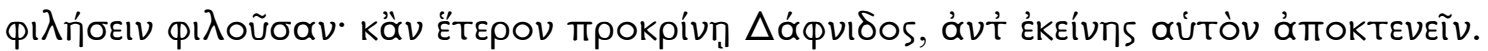

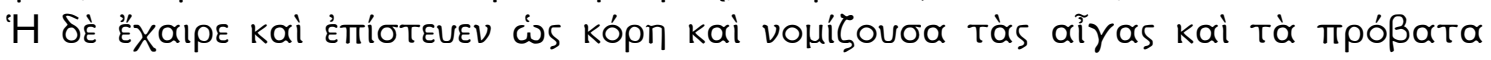

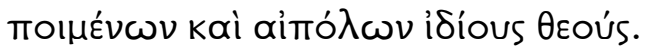




\title{
2. Tradução: Livro Segundo - Dáfnis e Cloé, de Longo de Lesbos
}

\author{
Livro segundo: Outono
}

[2.1] Como o outono já estivesse no ápice e fosse hora da vindima, todos estavam pelos campos em atividade. Um preparava os lagares, outro limpava os tonéis, um terceiro trançava cestas de vime. Este cuidava da pequena foice de cortar os cachos, e aquele da pedra de prensar o sumo dos cachos, e aquele outro do vime seco, a golpes descascado, para que, de noite, sob a luz de archotes, o mosto pudesse ser trazido.

Assim então, sem cuidar das cabras e das ovelhas, Dáfnis e Cloé ofereciam aos outros a ajuda de suas mãos. Ele carregava nos cestos de vime os cachos de uva e calcava-os aos pés, depois de os lançar nos lagares, e levava o vinho até os tonéis. Ela, por sua vez, preparava a refeição para os vindimadores e vertia para eles como bebida o vinho antigo e colhia uvas das videiras mais rasteiras. É que toda videira na região de Lesbos é rasteira, não sendo nem alta nem trepadeira, mas a estender no chão os ramos e a espalhar-se como hera. Mesmo um bebê poderia alcançar os cachos, caso livrasse suas mãos dos cueiros.

[2.2] E como é natural na festa de Dioniso e da origem do vinho, as mulheres das fazendas vizinhas, chamadas para ajudar, lançavam seus olhares sobre Dáfnis e elogiavam sua beleza como igual à de Dioniso, e uma das mais assanhadas até o beijou, o que atiçou Dáfnis, mas incomodou Cloé. Já os homens nos lagares lançavam variados gritos na direção de Cloé e como Sátiros sobre uma bacante saltavam o mais insanamente e oravam para se tornarem ovelhas e serem pastoreados por ela. E como por sua vez ela gostasse disso, foi Dáfnis quem ficou incomodado. Eles oravam mesmo é para que a vindima tivesse fim o mais depressa e eles retomassem a suas paragens habituais e ouvissem, ao invés dessa gritaria desafinada, os sons da flauta ou dos seus rebanhos a balir.

E depois de poucos dias, quando as videiras tinham sido colhidas, os tonéis guardavam o mosto e nada mais exigia a assistência de inúmeras mãos, eles desceram com seus rebanhos para o pasto e com muita alegria reverenciaram as Ninfas, ofertando-lhes cachos de uva nos ramos, primícias da vindima. Em momento anterior, nenhuma vez passaram por ali negligentes; ao contrário, eles sempre vinham frequentá-las no começo do pastoreio e ao fim passavam para saudá-las. E de tudo lhes ofertavam, flor ou fruto ou folhagem verde ou libação de leite. E depois dessas ações receberam dádivas da parte dos deuses. Por esse tempo, cães libertos dos grilhões, como dizem, eles saltavam, flauteavam, cantavam e com os bodes e as ovelhas travavam lutas. 
[2.3] Repletos de alegria, eis que um velho vem até eles envergando um manto de pele de cabra, calçado com botas rústicas, um alforje atravessado, um alforje muito velho. Sentando-se perto dos dois, ele falou assim:

- Eu sou o velho Filetas, oh jovens, que muito cantei para estas Ninfas aí, muito flauteei para aquele Pã ali e um rebanho imenso de bois tangi apenas com a minha música. Venho até vocês para revelar quanto vi, para declarar quanto ouvi. Sou dono de um pomar que, desde que abandonei o pastoreio por causa da velhice, plantei com minhas mãos. Tudo quanto trazem as estações tenho para mim a cada estação. Na primavera, rosas e lírios e jacintos e violetas de ambos os tipos. No verão, papoulas e peras silvestres e maçãs de toda espécie. Agora, videiras e figueiras e romãzeiras e bagas verdes de mirto. A este pomar acorrem bandos de pássaros pela manhã, uns para comer, outros para cantar - pomar escondido e repleto de sombras e por três fontes irrigado. Se alguém removesse o muro, pensaria ver um bosque. [2.4] E hoje, quando eu me aproximava, por volta do meio-dia, sob as romãzeiras e os mirtos um menino me surge aos olhos, com bagas de mirto e romãs nas mãos, alvo como o leite, louro como o fogo, luminoso como se recém banhado. Estava desnudo, estava sozinho. Brincava de colher frutas como se o pomar fosse seu. Eu então me precipitei sobre ele, para agarrá-lo - temia que, em sua petulância, ele quebrasse os mirtos e as romãzeiras. Mas ele me fugia com facilidade e passo ágil, umas vezes se ocultando sob as roseiras, outras se escondendo sob as papoulas, como um filhote de perdiz. É certo que muitas vezes tive dificuldades ao perseguir cabritos jovens, muitas vezes me esgotei ao correr atrás de novilhos recém-paridos. Mas esse era um espécime diferente e impossível de se capturar. Cansado, então, por ser velho, e apoiado em meu cajado e ao mesmo tempo vigiando para que ele não fugisse, procurei saber de qual dos vizinhos ele era e o que pretendia ao colher em pomar alheio. Ele não me respondeu nada; perto, parado, apenas sorria com grande doçura e me acertava bagas de mirto - e não sei como ele me enfeitiçava a ponto de eu não ficar irritado. Pedi então que ele viesse até minhas mãos sem nada mais temer, e jurei pelos mirtos que o deixaria livre, dando-lhe ademais maçãs e romãs, e que lhe permitiria sempre colher plantas e coligir flores, caso eu obtivesse dele um beijo apenas. [2.5] Ele então, após uma gargalhada ruidosa, libera uma voz que nem uma andorinha, nem um rouxinol, nem um cisne tão velho quanto eu possui:

- A mim, oh Filetas, nada impede de beijá-lo. Quero ser beijado mais do que você quer tornar-se jovem. Veja, porém, se meu presente combina com sua velhice: a velhice não o impedirá de tentar perseguir-me depois de um único beijo. Sou difícil de capturar mesmo por gavião e águia e qualquer outro pássaro mais veloz que estes. Não sou, com certeza, uma criança, mesmo se pareço criança; sou, contudo, mais antigo do que o Tempo e do que o próprio universo. 
E conheço você desde que pastoreava na flor da idade naquele monte seu robusto gado; eu ficava sentado ao seu lado, enquanto você flauteava junto daqueles carvalhos, no tempo em que estava apaixonado por Amarílis. Mas você não me via, embora bem perto eu estivesse da sua garota. Para você então eu a concedi e ela lhe deu filhos, excelentes vaqueiros e agricultores. Agora, contudo, sou pastor de Dáfnis e Cloé. E toda vez que os reúno a cada manhã, venho ao seu pomar e me encanto com as flores e as plantas e nestas fontes me banho. Por esse motivo são belas as flores e as plantas - com os meus banhos são regadas. Repare que nenhuma das suas plantas foi quebrada, nenhum fruto foi arrancado, nenhuma raiz de flor foi pisoteada, nenhuma fonte foi turvada - e alegre-se de ser o único dentre os homens na velhice a contemplar esta criancinha.

[2.6] Depois de dizer estas coisas, saltou como se fosse um filhote de rouxinol por cima dos mirtos e, pulando de galho em galho por entre as folhas, alcançou o cume. Vi asas em seu dorso e um pequenino arco em meio às asas, e nada mais vi, nem isso, nem ele. Se não foi à toa que ganhei estes cabelos brancos nem, ao ficar velho, adquiri o mais inútil juízo - ao Amor, oh crianças, vocês estão consagrados e Amor é quem ora cuida de vocês.

[2.7] Muito encantados eles ficaram como se ouvissem um mito, não um relato, e procuraram saber o que afinal é o Amor, se criança ou pássaro, e do que é capaz. Outra vez então Filetas disse:

- É um deus, minhas crianças, o Amor, jovem e belo e alado. Por isso se alegra com a juventude e persegue a beleza e leva as almas às alturas. Nem Zeus pode tanto quanto ele. Ele reina sobre os elementos, reina sobre os astros, reina sobre os deuses seus iguais - nem vocês têm tanto poder sobre suas cabras e ovelhas. As flores todas, trabalhos do Amor; as plantas todas, criação dele. Por sua causa correm rios e sopram ventos. Eu conheci até touro vitimado pela paixão; como se atingido por um aguilhão, não parava de mugir. E bode que desejava a cabra, perseguindo-a por toda a parte. Eu próprio era jovem e caí apaixonado por Amarílis. E nem do alimento me lembrava, nem água levava à boca, nem o sono conciliava. Eu sentia dor em minha alma, palpitação em meu peito, frio em meu corpo. Gritava como ferido, silenciava como morto, nos rios me lançava como em chamas. Invocava Pã auxiliador, que também ele próprio caiu enamorado da ninfa Pítis. Eu louvava a ninfa Eco que, depois de mim, chamava pelo nome de Amarílis. Quebrava as flautas, que enfeitiçavam minhas vacas, mas não me traziam Amarílis. Para a paixão não há nenhum remédio que se possa beber ou comer ou dizer em canções, senão beijo e abraço e deitar-se com os corpos nus.

[2.8] Filetas, depois de lhes ensinar estas coisas, afasta-se, levando alguns queijos que eles lhe deram e um novilho já com cornos. Quando ficaram sozinhos, após ouvir pela primeira vez o nome do Amor, tiveram suas almas cobertas de 
pesar e, de noite, de retorno aos estábulos, passaram a comparar o que sentiam com o que ouviram:

- Os amantes sofrem; nós também. Deixam de se alimentar; nós igualmente. Não conseguem dormir - é isso o que sofremos agora. Parecem arder; há fogo dentro de nós. Desejam olhar um para o outro - eis o motivo por que oramos para o dia surgir o mais depressa. Talvez isso seja o amor e amamonos sem o saber. Pois se isso não é o amor, e eu estou amando, por que então sofremos assim, por que ansiamos um pelo outro? Tudo o que Filetas disse é verdade. A criancinha do pomar também surgiu aos nossos pais naquele sonho e ordenou que guardássemos os rebanhos. Como alguém poderia capturá-la? É pequena e fugirá. E como alguém poderia fugir dela? Possui asas e o arrebatará. Precisamos recorrer às Ninfas auxiliadoras. Mas nem Pã socorreu Filetas apaixonado por Amarílis. Precisamos, então, ir atrás de todos os remédios que ele disse, beijo e abraço e deitar nus no chão. Está frio, mas resistiremos, seguindo Filetas.

[2.9] Uma escola noturna isso se torna para eles. E no dia seguinte, depois de conduzir os rebanhos ao pasto, beijaram-se assim que se viram (o que não faziam antes) e abraçaram-se, entrelaçando os braços. No terceiro remédio hesitaram - deitarem-se despidos. Era muito atrevimento não só para a donzela mas até mesmo para o jovem cabreiro. De novo então vem a noite com a insônia e o pensamento no que aconteceu e a censura pelo que não aconteceu.

- Beijamo-nos e de nada valeu. Abraçamo-nos e não tivemos resultado. Então o único remédio para a paixão é o deitar-se juntos. Precisamos tentar também isso - com certeza há aí algo que supera o beijo.

[2.10] Por causa de tais pensamentos, como é natural, tiveram sonhos eróticos, com beijos, com abraços. E tudo o que não fizeram de dia, em sonho o fizeram: nus, eles se deitaram um com o outro.

Mais empolgados, de fato, pelo dia seguinte, eles se levantaram e com rapidez desceram ao pasto com seus rebanhos, apressados para beijar. E logo que se viram, correram um para o outro sorrindo. Eles então se beijaram e em seguida se abraçaram - mas o terceiro remédio tardava, já que nem Dáfnis ousava dizêlo nem Cloé queria ser a primeira, até que por acaso fizeram isto...

[2.11] Sentados no tronco sob o carvalho, próximos um do outro a saborear a delícia dos beijos, encheram-se de um prazer sem limites. Os abraços exerciam pressão nos corpos. E por causa de um abraço um pouco mais forte de Dáfnis, que a puxava para si, eis que Cloé se deita de costas; e ele, perseguindo-lhe o beijo, deita-se sobre ela. E por reconhecerem a imagem dos sonhos, permaneceram deitados assim por muito tempo, como se atados. Sem saber de nada a partir daí e por achar que esse era o limite da fruição amorosa, eles se separaram, depois de gastar em vão a maior parte do dia, e recolheram os 
rebanhos, com ódio da noite. Talvez até fizessem algo de verdade, não fosse certo tumulto surpreender toda aquela região.

[2.12] Jovens ricos de Metimne, desejosos de aproveitar a vindima em lazer no estrangeiro, lançaram ao mar um pequeno barco, estabelecendo como remadores seus escravos domésticos, e navegaram costeando os campos dos mitilenos próximos ao mar. A praia era um bom ancoradouro, além de ricamente adornada com habitações e inúmeros lugares de banho e parques e bosques, uns feitos pela natureza, outros, pela arte dos homens - tudo ótimo para a satisfação de jovens. Costeando e ancorando, eles não faziam mal algum, apenas desfrutavam de variados lazeres, ora pescando do recife peixes que viviam entre as pedras, com anzóis de delicado linho pendurados em varas, ora capturando, com cães e redes, lebres que fugiam do alvoroço nas videiras; já agora estavam interessados na caça de pássaros e pegaram com redes gansos selvagens e patos e abetardas, de sorte que o lazer também lhes oferecia o benefício da mesa. E se precisavam de algo, buscavam-no entre as pessoas dos campos, pagando muito mais óbolos do que o justo. Careciam apenas de pão e vinho e pouso - não lhes parecia seguro, por ser estação outonal, permanecer no mar, de sorte que até o barco eles puxavam para a terra, de noite, temerosos de uma noite tempestuosa.

[2.13] Eis que um dos camponeses, precisando de corda para erguer a pedra de espremer os cachos de uvas já pisados, uma vez que a antiga arrebentara, veio escondido pela praia e, acercando-se do barco sem vigia, desatou o cabo e levou-o para casa, para utilizá-lo naquilo que precisava.

Desde o começo da manhã, os rapazes metimnianos deram busca pelo cabo e, como ninguém confessasse o roubo, zarparam, não sem antes censurar minimamente seus anfitriões. E longe dali trinta estádios, atracam nos campos em que moravam Dáfnis e Cloé, pois o lugar lhes pareceu bom para a caça de lebres. Mas corda para amarrar como cabo eles não tinham; então, trançando um longo vime verde como corda, com ele amarraram o barco a partir da popa até a terra firme. Em seguida, depois de soltar os cães para farejarem, colocaram redes nos lugares dos caminhos que pareciam oportunos. Acontece que os cães, a um só tempo correndo e latindo, assustaram as cabras e elas, abandonando as montanhas, apressaram-se na direção da praia. E sem ter nada para comer na areia, as mais ariscas dentre elas, ao se aproximarem da nau, o vime verde - que mantinha o barco preso - elas o devoraram.

[2.14] Havia certa agitação no mar, o vento soprando desde as montanhas. E de fato, com muita rapidez, o fluxo e refluxo das ondas empurrou o barco solto e carregou-o para o alto mar. Dentre os metimnianos, uma vez percebido o fato, uns correram na direção da praia, outros recolheram os cães. E todos gritaram, a tal ponto que todos os dos campos próximos ouviram e acudiram. Mas não havia 
socorro: com o vento soprando vigoroso, o barco era levado com rapidez irrefreável pela correnteza.

Os metimnianos então, privados de não poucos bens, procuraram por quem pastoreava as cabras. E ao encontrar Dáfnis, começaram a agredi-lo, a despi-lo. Um, sacando a coleira de um cão, até tentou torcer-lhe os braços para trás a fim de algemá-los. Ele gritava enquanto apanhava e suplicava aos camponeses e chamava em seu auxílio Lamon e Drias, sobretudo. Eles então opuseram resistência, por serem velhos fortes cujos braços vigorosos foram moldados pelos trabalhos com a terra, e consideraram justo que os acontecimentos fossem arbitrados por um juiz.

[2.15] Com a anuência dos outros, nomeiam Filetas, o vaqueiro, como árbitro. Era ele o mais velho dentre os presentes e tinha fama entre os aldeões de uma retidão extraordinária. Em primeiro lugar, os metimnianos fizeram a acusação com clareza e brevidade, já que tinham um vaqueiro como árbitro:

- Viemos a estes campos desejando caçar. Então, após prender nosso barco com vime verde sobre a costa, deixamo-lo ali, enquanto nós próprios com os cães fomos em busca de caça. Nisso as cabras dele, descendo até a praia, devoram o vime e soltam o barco. Você o viu sendo levado pelo mar, sabe cheio de quantos bens? Quanta roupa está perdida, quantos equipamentos para cães, quanta prata! Alguém dispondo daquilo poderia comprar estes campos. Em compensação, julgamos correto levar esse aí, já que é um cabreiro ordinário, que pastoreia suas cabras na praia, como se fosse um marujo.

[2.16] Com estas palavras os metimnianos acusaram. Dáfnis estava indisposto por causa das lesões, mas vendo Cloé presente, ignorou todos e falou assim:

- Eu pastoreio muito bem as minhas cabras. Jamais um único aldeão reclamou que uma cabra minha pastasse em seu pomar ou lhe quebrasse uma videira ainda em broto. Eles é que são caçadores ordinários e possuem cães mal adestrados, que correm demais e latem forte, com o que enxotaram as cabras das montanhas e das planícies na direção da praia, como se fossem lobos. Mas elas devoraram o vime - claro, não havia na areia erva ou morangueira ou tomilho! Mas o barco se perdeu por causa do vento e do mar - isso é obra do mau tempo, não das cabras! Mas havia ali roupas e prata - e quem, em perfeito juízo, vai acreditar que um barco carregando tais coisas tivesse um vime como cabo?

[2.17] Depois de tais palavras, Dáfnis caiu no choro e infundiu nos camponeses grande piedade, de sorte que Filetas, o árbitro, jurou por Pã e pelas Ninfas que Dáfnis não tinha cometido injustiça alguma, nem suas cabras, mas o mar e o vento, para os quais há outros juízes.

Filetas, contudo, não conseguiu convencer os metimnianos com estas palavras. Movidos pelo ódio, eles tentaram de novo agarrar Dáfnis e queriam 
amarrá-lo. Os aldeões, então, provocados, avançam sobre eles como se fossem estorninhos ou gralhas, e rapidamente arrebatam Dáfnis, que também já lutava, e batendo neles com paus depressa os puseram em fuga. E não recuaram antes que os expulsassem para além dos limites, para outros campos.

[2.18] Enquanto aqueles perseguem os metimnianos, Cloé com muita calma conduz Dáfnis à gruta das Ninfas e lhe lava o rosto coberto de sangue por algum golpe que lhe ferira as narinas, e do alforje sacando um naco de pão fermentado e uma fatia de queijo, dá-lhe de comer. E para revigorá-lo mais ainda, deu-lhe, com seus lábios macios, um beijo doce como o mel.

[2.19] Nessa ocasião, Dáfnis escapou de um mal imenso. Mas a questão não estava encerrada, pois os metimnianos, logo que chegaram penosamente à sua terra, caminhando e não navegando, maltrapilhos e não suntuosos, convocaram uma assembleia de cidadãos e, depositando diante deles ramos de oliveira, suplicaram ser dignos de vingança, sem dizer nenhuma palavra verdadeira - não queriam tornar-se risíveis por terem sofrido tantas e tais coisas nas mãos de pastores - mas apenas acusando os mitilenos, que os tinham privado do barco e pilhado suas riquezas, como se na lei da guerra. E eles, acreditando por causa das feridas e considerando justo vingar os rapazes das primeiras casas, votaram por uma guerra não declarada contra os mitilenos. Ordenaram que o general pusesse no mar dez barcos e devastasse o litoral daqueles. Por estar perto o inverno, não era seguro confiar ao mar uma frota maior.

[2.20] No dia seguinte, depois de reunir soldados remadores, ele passou imediatamente a atacar os campos costeiros dos mitilenos. E capturou muitos rebanhos, muito grão e vinho, já que se encerrara a vindima, e não poucos homens, todos os que estavam trabalhando. Atacou ainda os campos de Cloé e Dáfnis, e com um rápido desembarque, conduziu como butim tudo o que estava à mão.

Dáfnis, nesse momento, não pastoreava suas cabras, pois tinha subido à floresta para cortar folhagem verde, alimento para oferecer aos cabritos durante o inverno. Assim, do alto, ao contemplar a incursão, escondeu-se no tronco oco de uma faia seca. Cloé, por sua vez, estava junto de seus rebanhos e, perseguida, refugiou-se na gruta das Ninfas, suplicante, e rogou clemência, em nome das deusas, tanto para os rebanhos que pastoreava quanto para ela. Mas não havia socorro: os metimnianos, depois de muito blasfemar das estátuas, conduziram os rebanhos e tangeram-na como se fosse cabra ou ovelha, batendo-lhe com varas.

[2.21] Com os barcos já repletos de toda espécie de saque, decidiram não navegar para mais além; ao contrário, fizeram o trajeto para casa, temerosos tanto do inverno quanto dos inimigos. Eles então se afastaram remando com dificuldade, pois não havia vento. Dáfnis, por sua vez, com a calma instaurada, ao chegar no lugar onde pastoreavam e não ver as cabras nem achar as ovelhas 
nem encontrar Cloé, mas apenas imenso abandono e até a flauta com que habitualmente Cloé se alegrava jogada ao chão, com ensurdecedores gritos e gemidos de causar dó, corria ora para o carvalho sob o qual se sentavam, ora na direção do mar tentando avistá-la, ora na direção da gruta das Ninfas, junto das quais ela tinha se refugiado antes de ser arrastada. E ali se jogou no chão e censurou as Ninfas de traição:

[2.22] - Das suas mãos Cloé foi raptada - e vocês toleraram assistir a isso? Ela que trança guirlandas para vocês, ela que derrama o primeiro leite, de quem também esta flauta é um presente? Nenhuma cabra minha lobo algum capturou, mas os inimigos, o rebanho inteiro e a que pastoreava comigo! As cabras eles vão esfolar e as ovelhas sacrificar, e Cloé, de agora em diante, vai habitar uma cidade. Com que cara irei até meu pai e minha mãe sem as cabras, sem Cloé, desgraçado que sou? Nada mais tenho para pastorear. Aqui caído esperarei a morte ou uma segunda guerra. Também você, Cloé, sofre assim? Acaso se recorda deste lugar e destas Ninfas e de mim? Ou as ovelhas e as cabras a consolam, elas que com você foram aprisionadas?

[2.23] Assim que diz tais palavras, um sono profundo o arrebata das lágrimas e da tristeza. E diante dele surgem as três Ninfas, mulheres altas e belas, seminuas e descalças, os cabelos soltos e iguais às estátuas. Pareciam, primeiro, sentir pena de Dáfnis; mas depois, a encorajá-lo, diz-lhe a mais velha:

- Não nos censure, Dáfnis. Nós nos preocupamos com Cloé mais do que você. Fomos nós que sentimos pena dela e a nutrimos quando era uma bebezinha e fora exposta nesta gruta. Não há nada em comum entre ela e estas planícies. E já consideramos a questão, a fim de que ela nem se torne escrava conduzida a Metimne, nem seja parte do butim de guerra. Pã, aquele que tem morada sob o pinheiro, a quem vocês nunca honraram nem mesmo com flores, a ele solicitamos que seja o vingador de Cloé. Acostumado aos exércitos mais do que nós, muitas guerras já ele enfrentou, afastado do campo. Contra os metimnianos avança um inimigo nada agradável. Não sofra mais - levante-se e deixe que Lamon e Mírtale ponham os olhos em você, eles que também jazem ao chão, por julgarem que você também tornou-se parte do saque. Quanto a Cloé, amanhã ela vai voltar para você com as cabras, com as ovelhas, e vocês vão pastorear juntos e flautear juntos. E quanto ao resto, Amor cuidará de vocês.

[2.24] Depois de ver e ouvir tais coisas, Dáfnis saltou do sono e, com um choro misturado de prazer e tristeza, foi prostrar-se diante das estátuas das Ninfas e prometeu sacrificar-lhes a melhor das cabras, se Cloé fosse salva. Correndo ainda ao pinheiro, lá onde tem morada a estátua de Pã, com chifres, pés de bode, uma flauta em uma mão, na outra um bode saltitante, prostrou-se também diante dele e orou por Cloé e prometeu sacrificar-lhe um bode. E por fim, com dificuldade, perto do pôr do sol, após cessar suas lágrimas e suas preces 
e recolher as folhas que cortara, retornou ao estábulo. E assim que afastou os sofrimentos da família de Lamon e os cumulou de alegria, provou do alimento e foi dormir, não sem lágrimas, mas orando outra vez para ver em sonho as Ninfas e orando para que o dia seguinte chegasse logo, ocasião em que lhe prometeram Cloé. Aquela pareceu ser de todas as noites a mais longa - e nela tais coisas se cumpriram...

[2.25] O general dos metimnianos, depois de se afastar cerca de dez estádios, quis que seus soldados, cansados pela incursão, revigorassem. Assim, ao alcançar um promontório que avançava mar adentro em formato de lua, dentro do qual o mar moldava um refúgio mais calmo que os portos, ancorou ali os barcos, em águas profundas, a fim de que nenhum camponês da terra assediasse algum deles, e permitiu aos metimnianos um lazer pacífico. Como tinham abundância de tudo por causa da pilhagem, beberam, divertiram-se, imitaram uma festa de vitória.

Quando o dia já declinava e o lazer chegava ao fim por causa da noite, de repente a terra toda parecia arder em chamas e um clamor de remos a bater foi ouvido, como se uma expedição imensa estivesse atacando. Alguém gritava para que o general se armasse, um chamava pelo outro, e este parecia já estar ferido, e aquele jazia imitando a forma de um cadáver. Alguém pensaria estar vendo um combate noturno - sem inimigos presentes.

[2.26] Depois de uma tal noite para eles, sobreveio o dia ainda mais terrível do que a noite. Os bodes de Dáfnis e suas cabras ostentavam nos chifres cachos de hera, enquanto os carneiros e as ovelhas de Cloé uivavam como lobos. E ela própria apareceu engrinaldada com ramos de pinheiro. E no mar também aconteciam muitas coisas surpreendentes. As âncoras permaneciam no fundo, se tentavam recolhê-las; os remos se partiam, se os baixavam para remar; e golfinhos pulando das águas e batendo com as caudas nos barcos afrouxavam as cavilhas. E da pedra íngreme do alto do promontório um som de flauta foi ouvido - mas não encantava como uma flauta: amedrontava os ouvintes como uma trombeta. Eles então se agitaram e corriam em busca de armas e chamavam pelos inimigos que não eram vistos, de sorte que oraram para que a noite viesse outra vez, a fim de que com ela obtivessem trégua.

Então, a todos que tinham o juízo no lugar os acontecimentos tornaram-se inteligíveis - que as aparições e os sons eram obra de Pã, irritado com os marujos por algum motivo. Mas não tinham como interpretar a causa (pois nenhum templo de Pã fora saqueado), até que, por volta do meio do dia, o general precipitou-se no sono (não sem ajuda divina) e o próprio Pã lhe surgiu dizendo assim:

[2.27] - Oh mais impuros e ímpios dentre todos, por que ousaram tais coisas em seus corações insanos? Cumularam de guerra o campo que me é caro, 
capturaram rebanhos de bois e cabras e ovelhas dos quais eu cuido, arrancaram de altares uma donzela, com quem Amor quer compor um mito. E não tiveram pudor nem das Ninfas que os observavam, nem de mim, Pã. Então vocês não avistarão Metimne com tais despojos ao navegar, nem fugirão desta minha flauta que já os abalou. Eu farei de vocês comida de peixes, ao afundá-los, se você não restituir às Ninfas o mais depressa possível Cloé e os rebanhos de Cloé. Levante-se e desembarque a garota com tudo que eu disse. E eu conduzirei você em seu barco e ela em seu caminho.

[2.28] Muito agitado, então, Bríaxis (o general assim se chamava) deu um salto e, depois de chamar os comandantes dos barcos, ordenou que Cloé fosse procurada o mais rápido possível entre os cativos. Eles tão rápido a encontraram quanto trouxeram-na à sua vista - ela estava sentada, engrinaldada com ramos de pinheiro. Considerando isso também como símbolo da visão dos sonhos, ele a conduz no próprio barco principal até a terra. Ela apenas desembarca e o som de uma flauta começa de novo a ser ouvido da pedra, não mais bélico e assustador, mas pastoril e próprio para a condução de rebanhos ao pasto. E tanto as ovelhas se apressaram a desembarcar, furtivas, nas pontas dos cascos, quanto as cabras com muito mais ousadia, acostumadas que eram a escalar penhascos.

[2.29] E elas formam um círculo ao redor de Cloé como um coro de dançarinas, saltando e balindo e por igual se alegram. Já as cabras dos outros pastores e as ovelhas e os bois permaneceram no mesmo lugar dentro do côncavo barco, como se a melodia não os chamasse.

Enquanto todos estavam dominados pelo espanto e bendiziam Pã, prodígios mais espantosos do que estes surgiam em ambos os elementos. Com relação aos metimnianos, mesmo antes de içar as âncoras, os barcos já navegavam e um golfinho, saltando nas águas, conduzia o barco principal. Com relação às cabras e ovelhas, um som de flauta agradabilíssimo as conduzia, ainda que ninguém visse o flautista, de sorte que as ovelhas e as cabras avançavam e pastavam simultaneamente, encantadas pela melodia.

[2.30] Era perto da hora do segundo pastoreio e Dáfnis, ao avistar de um elevado mirante os rebanhos e Cloé e gritar forte: "Oh Ninfas e Pã!", desceu correndo até o campo e, enlaçado nos braços de Cloé, caiu desmaiado. Forçosamente trazido à vida por Cloé que o beijava e o aquecia com seus abraços, ele vai até o carvalho de costume. E depois de se sentar no tronco, procurou saber como ela tinha escapado de tantos inimigos. Ela the contou tudo em detalhe: a hera nas cabras, o uivo das ovelhas, o florescer do pinheiro sobre sua cabeça, o fogo em terra, o clamor no mar, os dois flauteados, o bélico e o pacífico, a noite assustadora, e como a ela, que não conhecia o caminho, uma música serviu de guia pelo caminho. 
Ao reconhecer, então, os sonhos das ninfas e os trabalhos de Pã, Dáfnis descreve também ele próprio quanto viu, quanto ouviu - que estando prestes a morrer, graças às Ninfas viveu. E a envia para buscar os familiares de Drias e Lamon e tudo o que é necessário para um sacrifício. Enquanto isso, ele próprio, depois de agarrar a melhor das cabras e coroá-la com hera, tal como tinham aparecido aos inimigos, e derramar libação de leite entre os chifres, sacrificou-a em nome das Ninfas e, erguendo-a, esfolou-a e pendurou a pele.

[2.31] Estando já presentes os familiares de Cloé, aceso o fogo e uma parte das carnes cozida, outra assada, ele ofereceu as primícias às Ninfas e libou com uma taça repleta de doce vinho. E assim que estendeu alguns leitos de folhas, ficou ali entre alimento e bebida e brincadeiras, ao mesmo tempo em que vigiava os rebanhos - um lobo, atacando, não fizesse os trabalhos de inimigos.

Cantaram também algumas canções para as Ninfas, composições de antigos pastores. E uma vez que a noite sobreveio e eles dormiram ali mesmo no campo, foi no dia seguinte que se lembraram de Pã. Depois de coroar com ramos de pinheiro o bode que liderava o rebanho, conduziram-no ao pinheiro, e assim que verteram vinho e bendisseram o deus, sacrificaram-no, penduraram-no, esfolaram-no. E as carnes assadas e cozidas colocaram próximas sobre a relva, sobre as folhas. E a pele com chifres e tudo penduraram no pinheiro em honra à estátua, uma oferenda pastoril a um deus pastoril. Ofertaram ainda as primícias das carnes e libaram com a maior taça. Cloé cantou, Dáfnis flauteou.

[2.32] Depois disso, reclinados, começaram a comer. E eis que deles se aproxima Filetas, o vaqueiro, por acaso, levando para Pã umas guirlandinhas e cachos de uva ainda com folhas e ramos. E com ele seguia Títiro, o mais novo de seus filhos, rapazinho ruivo e de olhos claros, alvo e altivo rapazinho. Ele saltitava leve, caminhando como um cabrito.

Eles então, com um salto pondo-se de pé, foram com ele coroar Pã e pendurar os ramos na folhagem do pinheiro e, em seguida, sentando-o próximo deles, fizeram dele um conviva. E de fato, como velhos levemente embriagados, falaram muitas coisas uns para os outros: como pastoreavam no tempo em que eram jovens, como escaparam de numerosas incursões de piratas; um se gabava de ter matado um lobo, o outro de que com a flauta ficava atrás apenas de Pã esse era o orgulho de Filetas.

[2.33] Então Dáfnis e Cloé lhe fizeram muitas súplicas para que partilhasse também com eles sua arte e flauteasse na festa do deus que se rejubila com a flauta. Filetas concordou, não sem censurar a velhice por seu pouco fôlego, e pegou a flauta de Dáfnis. Contudo, ela era pequena demais para sua imensa arte, já que era soprada pela boca de um garoto. Ele envia então Títiro até sua casa, afastada dali dez estádios, para buscar sua própria flauta. Despindo seu avental, nu, ele então começou a correr, como um filhote de corça. Enquanto isso, Lamon 
declarou a eles que contaria em detalhe o mito da flauta, que para ele um pastor siciliano cantou em troca de um bode e de uma flauta:

[2.34] - Esta flauta, o instrumento, não era um instrumento, mas uma bela virgem de voz maviosa. Pastoreava cabras, brincava com as Ninfas, cantava tal como agora. Pã, quando ela pastoreava e brincava e cantava, se aproximou e tentou induzi-la àquilo que ele desejava, e prometeu que todas as suas cabras paririam gêmeos. Ela riu de sua paixão e disse que não aceitaria um amante que não era nem bode nem homem por inteiro. Pã começa a persegui-la pretendendo usar a violência. Siringe ${ }^{1}$ tentou evitar Pã e sua violência. Cansada de fugir, ela se esconde entre juncos e no pântano desaparece. Pã, depois de cortar irado os caniços, sem encontrar a garota, e compreender seu sofrimento, inventa o instrumento, ao juntar os caniços desiguais com cera, como também para eles era desigual a paixão. E eis que a bela jovem é agora uma flauta melodiosa.

[2.35] No momento em que Lamon interrompera a narrativa mítica e Filetas o elogiava por contar um mito mais doce que uma canção, Títiro surge com a flauta do pai, um instrumento enorme e de grandes canas, e que era unido com cera, trabalhado em cobre. Alguém poderia pensar ser ela aquela primeira que Pã construiu. Então Filetas, depois de se erguer e se arrumar em seu assento corretamente, testou primeiro os caniços, para ver se o ar passava bem. Depois, percebendo que o ar corria sem impedimento, soprou a partir daí muito e com jovialidade. Alguém seria levado a pensar que ouvia várias flautas tocando ao mesmo tempo, de tal modo ecoava o som da flauta. E diminuindo o vigor pouco a pouco, passou para a mais sutil melodia. Demonstrando então toda sua arte de acordo com as leis musicais, passou a flautear como convém ao rebanho de bois, como é adequado ao rebanho de cabras, como é agradável ao rebanho de ovelhas. Era sutil o dos rebanhos de ovelhas, forte o dos bois, estridente o das cabras. E uma só flauta imitava completamente todas as flautas.

[2.36] Os outros, então, permaneciam reclinados, em silêncio, encantados. Drias, contudo, ao se levantar e pedir-lhe que flauteasse uma melodia dionisíaca, dançou para eles uma coreografia de vindima - e parecia que ele ora colhia uvas, ora carregava os cestos de vime, depois calcava aos pés os cachos, depois enchia os tonéis, depois bebia o doce vinho. Tudo isso Drias dançou com tão elegante figura e clareza que eles acreditavam ver as videiras e o lagar e os tonéis e Drias bebendo de verdade.

[2.37] Este terceiro velho, então, aplaudido pela dança, beija Cloé e Dáfnis. E eles, depois de se levantar com muita rapidez, dançaram o mito de Lamon. Dáfnis imitava Pã, Cloé, Siringe. Ele suplicava, tentando seduzi-la, e ela, negligente, sorria. Ele a perseguia e, imitando cascos, corria nas pontas dos pés,

\footnotetext{
1 Siringe, isto é, flauta.
} 
e ela em fuga demonstrava seu cansaço. Então Cloé se escondeu na floresta, como se no pântano, e Dáfnis, depois de pegar a flauta enorme de Filetas, tocou de modo dolorido como se a amasse, de modo erótico como se a desejasse, de modo evocativo como se a buscasse - de sorte que Filetas, admirado, de pé com um salto, beija-o e, depois de beijá-lo, presenteia-o com a flauta e roga ainda a Dáfnis que a deixe como herança a um igual sucessor.

[2.38] Ele então, após dedicar sua própria flauta a Pã, a pequena, e beijar Cloé como se encontrada de fuga verdadeira, foi guardar o rebanho a flautear com a noite já chegando. Também Cloé recolheu seu rebanho, cantando junto com a melodia da flauta. E as cabras seguiam próximas das ovelhas, assim como Dáfnis caminhava perto de Cloé, de sorte que se saciaram um com o outro até de noite e combinaram descer ao pasto com os rebanhos mais cedo no dia seguinte. E assim fizeram...

Precisamente quando começava o dia, foram ao pasto. E depois de saudar as Ninfas em primeiro lugar, em segundo Pã, a partir daí sob o carvalho sentados começaram a flautear. Em seguida, se beijaram, se abraçaram, se deitaram, e sem nada mais fazer, se levantaram. Cuidaram então de alimentar-se, e beberam vinho misturado ao leite.

[2.39] E por tudo isso ficando mais ardentes e atrevidos, lutavam um com o outro uma luta erótica, e pouco tempo depois chegaram a confidenciar juras. Ele então jurou por Pã, depois de ir até o pinheiro, que não viveria sozinho, sem Cloé, nem o tempo de um só dia. E Cloé, depois de se dirigir à gruta, pelas Ninfas jurou que teria o mesmo destino que Dáfnis, tanto morte quanto vida. De tal modo, com efeito, era a ingenuidade dela, por ser garota, que, ao sair da gruta, achou por bem tomar uma segunda jura dele, dizendo:

- Oh Dáfnis, Pã é um deus lascivo e infiel. Ele amou Pítis, amou Siringe. E nunca para de incomodar as Dríades e oferecer coisas às Ninfas Epimélides. Ele então, por ser negligente nas juras, negligenciará punir você, mesmo se você buscar mais mulheres do que os caniços em sua flauta. Jure para mim em nome deste rebanho de cabras e daquela cabra que amamentou você, que não abandonará Cloé, enquanto ela permanecer fiel a você. Se ela for desleal a você e às Ninfas, fuja e a odeie e a mate como a um lobo.

Dáfnis gostou da desconfiança e de pé no meio do rebanho, com uma cabra em uma das mãos, na outra um bode, jurou que amaria Cloé enquanto ela o amasse. Que mesmo se ela preferisse outro, e não Dáfnis, em vez dela ele mataria a si mesmo. Ela ficou contente e convencida, como garota, por julgar as cabras e as ovelhas deuses próprios de pastores e cabreiros. 


\section{REFERÊNCIAS}

LIDDELL, H. G.; SCOTT, R. A Greek-English Lexicon. Revised and augmented throughout by Sir Henry Stuart Jones with the assistance of Roderick McKenzie. Oxford: Clarendon Press, 1940.

LONGO. Dáfnis e Cloé. Tradução de Duda Machado. São Paulo: Princípio Editora, 1996.

LONGO. Dafnis y Cloe. AQUILES TACIO. Leucipa y Clitofonte. JÂMBLICO, Babiloníacas. Introducciones, traducciones y notas de Máximo Brioso Sanches y Emilio Crespo Güemes. Madrid: Gredos, 1997 [1ª edição 1982].

LONGUS. Daphnis and Chloe. Translated and introducted by Paul Turner. England: Penguin Book, 1968.

LONGUS. Erotici Scriptores Graeci, vol. 1. Rudolf Hercher. Leipzig: Teubneri, 1858. (Hospedado em Perseus Digital Library). Disponível em: http://www.perseus.tufts.edu/hopper/text?doc=Longus+\&fromdoc=Perseus \%3Atext\%3A2008.01.0642 Acesso em 23.out.2020.

MALHADAS, D.; DEZOTTI, M. C. C.; NEVES, M. H. M. Dicionário GregoPortuguês. Cotia: Ateliê, 2006-2010.

Data de envio: $18 / 05 / 2020$

Data de aprovação: 29/06/2020

Data de publicação: 21/12/2020 